VIII.-Report on the Pennatulida dredged by H.M.S. "Triton." By A. Milnes Marshald, M.D., D.Sc., M.A., Fellow of St John's College, Cambridge, Beyer Professor of Zoology in Owens College. (Plates XXI. to XXV.)

(Read 16th July 1883.)

\title{
INTRODUCTION.
}

The Pennatulida obtained by H.M.S. "Triton," and placed in my hands for description, are of six genera only, each genus being represented by a single species. The interest of the collection is, however, far from commensurate with its size, for of the six species two are altogether new to science, a third has hitherto been met with only off the Norwegian coast, while concerning the remainder, which are well known species, the "Triton" specimens have furnished important additions to our knowledge, either of their anatomy or distribution.

In arranging the species $I$ have followed the system of classification proposed by Kölliker in his "Report on the Pennatulida dredged by H.M.S. 'Challenger.'"* This scheme, though representing the latest results of our greatest authority on the group, cannot be considered altogether satisfactory, inasmuch as but very little attempt is made to express the mutual relations of the several groups, and highly specialised forms are mixed up with more primitive ones in a very confusing manner. I have, however, thought it better to adopt it here rather than attempt to frame a new scheme on inadequate material.

The following outline of KöLLIKER's classification shows the position occupied by the genera with which we are concerned :-

\section{Order PENNATULIDA.}

Section I. Pennatulea: polyps fused together to form leaves.

Sub-section 1. Penniformes: leaves well developed.

Family 1. Pteroeididæ.

Family 2. Pennatulidæ.

Genus Pennatula.

Sub-section 2. Virgulariece: leaves small.

Family 1. Virgularidæ.

Genus Virgularia.

Family 2. Stylatulidæ.

Genus Dïbenia.

* Zool. Chall. Exp., part ii. pp. 33-35, 1880. 
Section II. SPICATa : no leaves ; polyps sessile.

Sub-section 1. Funiculinea : polyps arranged in distinct rows.

Family 1. Funiculinidæ.

Genus Funiculina.

Family 2. Stachyptilidæ.

Family 3. Anthoptilidæ.

Sub-section 2. Junciformes: polyps in single series or in indistinct rows.

Family 1. Kophobelemnonidæ.

Genus Kophobelemnon.

Family 2. Umbellulidæ.

Genus Umbellula.

Family 3. Protocaulidæ.

Family 4. Protoptilidæ.

Section III. Renillek : rachis expanded, in form of a leaf.

Section IV. VereTILLEe: polyps arranged on rachis in radiate manner.

The following table shows the localities at which the specimens were obtained, the number taken at each, and the instrument employed in each case. The specimens taken at Stations 6 and 7 do not belong to the "Triton" collection, but were dredged by the "Knight Errant" in 1880 :-

\begin{tabular}{|c|c|c|c|c|c|c|}
\hline Station. & Locality. & $\begin{array}{l}\text { Depth in } \\
\text { Fathoms. }\end{array}$ & Date. & Name. & Number. & $\begin{array}{c}\text { How } \\
\text { Caught. }\end{array}$ \\
\hline $\begin{array}{c}6 \\
7 \\
8 \\
10 \\
\\
11\end{array}$ & $\begin{array}{c}59^{\circ} 37^{\prime} \mathrm{N}^{\prime}, 7^{\circ} 19^{\prime} \mathrm{W} . \\
\text { do. do. } \\
60^{\circ} 18^{\prime} \text { N., } 6^{\circ} 15^{\prime} \mathrm{W} . \\
59^{\circ} 40^{\prime} \text { N., } 7^{\circ} 21^{\prime} \mathrm{W} . \\
59^{\circ} 29^{\prime} 30^{\prime \prime} \mathrm{N}^{\prime}, 7^{\circ} 13^{\prime} \mathrm{W} .\end{array}$ & \}$_{40}^{35-37}$ & $\begin{array}{l}\text { Aug. 11, } 1880 \\
\text { Aug. 12, } 1880 \\
\text { Aug. 22, } 1882 \\
\text { Aug. 24, } 1882 \\
\text { Ang. 28, } 1882\end{array}$ & $\begin{array}{c}\text { Kophobelemnon } \\
\text { Pennatula } \\
\text { Kophobelemnon } \\
", \\
\text { Pennatula } \\
\text { Virgularia } \\
\text { Dübenia } \\
\text { Kophobelemnon } \\
\text { Umbellula } \\
\text { Funiculina } \\
\text { Pennatula }\end{array}$ & $\begin{array}{c}1 \\
1 \\
2 \\
3 \\
2 \\
18 \\
1 \\
2 \\
1 \text { fragment } \\
1 \\
13 \\
11 \& 6 \text { heads } \\
1 \\
10 \text { fragments } \\
4\end{array}$ & $\begin{array}{l}\text { Trawl } \\
\text { Dredge } \\
\text { Trawl } \\
\text { Dredge } \\
\text { Trawl } \\
\text { Dredge } \\
\text { Trawl } \\
\text { Trawl } \\
\text { Dredge } \\
\text { Trawl } \\
\\
\text { Trawl }\end{array}$ \\
\hline
\end{tabular}


Concerning the mode of capture, it will be seen from the above table that the trawl was distinctly more successful than the dredge; and the difference between the two is greater than appears from a mere comparison of the number of specimens taken, for the proportion of imperfect and mutilated specimens brought up by the dredge far exceeds that yielded by the trawl, the mutilation being in many cases clearly caused by the dredge itself.

For such forms as Pennatulida the dredge is indeed a very unsuitable instrument of capture; a point that deserves a greater amount of practical attention than it appears yet to have received.* It is certainly worthy of note that the three most interesting forms collected by the "Triton" were all brought up by the trawl.

Concerning the nomenclature adopted, I have retained the terms polyp and zooid for the two kinds of individuals, sexual and asexual, of which a Pennatulid colony normally consists, since these names are in general use. Strictly speaking, the names are objectionable, for the term zooid is commonly and conveniently employed in zoology to indicate any member of a colony that is produced asexually, and in this sense both kinds of individuals of the Pennatulid colony are zooids.

For the tubular cavity into which the mouth leads, and which is commonly spoken of as the stomach, I have adopted the term stomodaeum. This eavity is in no sense of the word entitled to the name of stomach, inasmuch as diges tion is effected, not in it, but in the body cavity into which it opens below. KöLLIKER has proposed to call it œesophagus, + but the term stomodoeum seems preferable, as indicating at once its origin by involution of the outer layer of the body or ectoderm.

\section{DeSCRIPTION OF THE SPECIMENS.}

Order PENNATULIDA.

Section I. Pennatulea.

Sub-section 1. Penniformes.

Family 2. Pennatulidæ.

\section{Pennatula, L.}

Pennatula phosphorea, L. (Pl. XXI. figs. 4-7, and Pl. XXII. figs. 8-16.)

This species was obtained by the "Triton" at two localities, off the Butt of Lewis in 40 fathoms water, and at Station 11 at a depth of 555 fathoms. The collection also includes a single specimen obtained by the "Knight Errant" in 1880.

* Cf. Nature. A new dredging implement, vol, xxvii. p. 11.

$\dagger \mathrm{K}$ ÖLIKER, Anatomisch-Systematische Beschreibung der Alcyonarien, p. 416, 1872. 
Of this very variable species KöLLIKER distinguishes three well-marked varieties, characterised as follows :*-

1. Var. angustifolia: Leaves long and narrow; polyp heads few and wide apart.

2. Var. lancifolia: Leaves lancet-shaped; polyp heads numerous, and close together. Of this form, which should probably be considered the typical $P$. phosphorea rather than a distinct variety, Kölliker further distinguishes four sub-varieties.

3. Var. aculeata: Leaves slender, and placed close together; on the ventral surface of the rachis are four to six rows of long spines, connected with the zooids.

Of the "Triton" specimens those obtained off the Butt of Lewis belong to the second variety lancifolia; while the more numerous specimens from the deeper water of Station 11 are typical examples of the variety aculenta. The two forms are so distinct that it will be well to describe them separately.

\section{P. phosphorea var. lancifolia, Köll.}

All four specimens are small, and of somewhat stunted appearance, the leaves being twisted in an irregular manner, so that sometimes the dorsal and sometimes the ventral border of the leaf is turned upwards. The four specimens, though of nearly the same absolute size and all obtained at one haul, differ a good deal among themselves as to the shape of the leaves and the breadth of their attachment to the rachis, and also as to the extent of separation between the component polyps of a leaf.

The zooids, which are uniform in size, cover the whole ventral surface of the rachis, except the mid-ventral groove, and extending upwards between the leaves, become continuous with small groups of three or four zooids each situated on the dorso-lateral angles of the rachis between the leaves.

In all four specimens the stalk, with the exception of the terminal dilatation, which is yellowish, is of a dark red colour, due, as in the rachis and leaves, to the calcareous spicules imbedded in it. In one specimen the colour is a deep purple of exceptional intensity.

The measurements of the four specimens in millimètres are as follows :-

\begin{tabular}{|c|c|c|c|c|}
\hline & A. & B. & C. & D. \\
\hline Length of colony, & $60 \mathrm{~mm}$. & $56 \mathrm{~mm}$. & $58 \mathrm{~mm}$. & $58 \mathrm{~mm}$. \\
\hline rachis, & 31.5 & 27 & 31 & 30 \\
\hline stalk, & $28 \cdot 5$ & 29 & 27 & 28 \\
\hline leaves, & 13 & 13 & 12 & $11 \cdot 5$ \\
\hline Greatest width of leaves, & 2 & $2 \cdot 5$ & 3 & 3 \\
\hline No. of leaves on each side, & 20 & 21 & 22 & 20 \\
\hline$"$ polyps per leaf, & 10 & 9 & 9 & 10 \\
\hline
\end{tabular}


From these figures it will be seen that specimens A and B approach very closely KöLLIKER's variety angustifoliu.

P. phosphorea var. aculeata, Köll. (Pl. XXI. figs. 4-7, and Pl. XXII. figs. 8-16.)

This very well-marked variety, which does not appear to have been hitherto recorded from British seas, is characterised by the long and slender shape of the leaves (Pl. XXI. figs. 4 and 5), the small number of their component polyps, their distance apart, and the extent to which they are separate from one another; and above all, by the fact that a number of the zooids of the ventral surface (figs. 4 and 5, $f$ ) are very exceptionally developed-assuming the form of conical spines, which project from the rachis for a distance in some specimens of $3.5 \mathrm{~mm}$., or even more.

This variety was first described in 1858 by KoREN and DANIELSSEN, who found it at a single locality near Christiansund, where it occurred rather abundantly on clay bottom at the depth of 80 to 100 fathoms. Since then it has been taken by SARS at Christiansund at a depth of 30 to 70 fathoms, and in the Throndhjemsfjord in 100 fathoms water; by CARPENTER and WrviLLE Thomson, during the "Porcupine" expedition in the Atlantic Ocean, $48^{\circ} 26^{\prime} \mathrm{N}$., $9^{\circ} 44^{\prime} \mathrm{W}$., at a depth of 358 fathoms; and by Whiteaves in the Gulf of St Lawrence, at a depth of 160 to 200 fathoms.

Of the "Triton" specimens of $P$. phosphorea, all those, 19 in number, obtained at Station 11, depth 555 fathoms, belong to this variety, as also does the single specimen from the "Knight Errant" collection dredged at Station 7, in 530 fathoms water. As the variety is a very interesting one, and has not yet been satisfactorily described, I have taken the opportunity afforded by the large number of specimens available to investigate in some detail the more important structural details, directing my attention more particularly to the large ventral zooids.

The following table gives the measurements of the single specimen from the "Knight Errant" and of two of the "Triton" specimens. All the latter are of small size, the specimen B being one of the largest.

A.

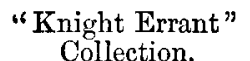

Length of colony, . . . $\quad$. $70 \mathrm{~mm}$.

" racbis, . $\quad . \quad$. 31

" stalk, . $\quad . \quad$. $\quad 39$

" leaves (longest), . . 12

Greatest width of leaves, . $\quad$. 3

Number of pairs of leaves, . $\quad$. 19

Number of polyps per leaf, . $\quad$. 9

Length of largest zooids, . . 3
B.

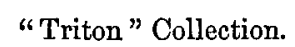

$62 \mathrm{~mm} . \quad 48 \mathrm{~mm}$.

$28.5 \quad 24$

$33 \cdot 5 \quad 24$

$13 \quad 10$

$1.5 \quad 1.5$

$14 \quad 10$

$6 \quad 7$

$35 \quad 3$

* Konen and Danielssex, Forhandlinger i. Videnskabsselskabet i. Christiania, p. 25, 1858 ; also Fauna Littoralis Norvegia, part iii. pp. 86-88, and pl. ii. figs. 8 and 9, Bergen, 1877. 
Koren and Danielssen, Whiteaves and Verrill, maintain the specific distinctness of this form from $P$. phosphorea. The measurements of the different specimens I have been able to examine show so great variability in the essential characters of the form, such as the length of the large zooids, width of leaves, \&c., that I can have no hesitation in agreeing with KöLLIKER* in regarding it as merely a variety, though a very well-marked one. I cannot, however, accept RICHIARDI's $\dagger$ conclusion that it is not even a variety, " ma uno stato puramente accidentale di certi exemplari."

The general appearance of the form is shown in Pl. XXI. fig. 4, representing an entire specimen seen from the right side and twice the natural size. Fig. 5 is a transverse section through the rachis about the middle of its length, with one of the attached leaves and the base of the corresponding leaf of the opposite side. For the sake of comparison, I have given in fig. 6 a similar view of a normal specimen of P. phosphorea obtained from Oban.

If these two figures be compared together, it will be seen that the points in which the variety aculeata (fig. 5) differs from the typical $P$. phosphorea (fig. 6) are the following :-The leaf is longer and much narrower; the polyps are fewer in number, are placed further apart, and are independent of one another for a greater portion of their length. The walls of the rachis are much thicker, a condition associated with the presence of larger and more numerous spicules; the axial calcareous stem is thicker, and the main longitudinal canals of the rachis much smaller than in the typical form. Concerning the zooids, it will be seen that a very large one (fig. $6, f$ ) arises from the rachis immediately below each leaf, with the ventral border of which it is fused for about a third of its length. Nearer the mid-ventral line of the rachis there is on each side a second row of large zooids, usually slightly smaller than those of the outer row, but sometimes equalling them in size; and within these again other zooids occur intermediate in size between the large ones and the normal small ones. The largest zooids, those attached to the ventral borders of the leaves, have an average length of rather over $3 \mathrm{~mm}$. in the "Triton" specimens; in exceptional cases they reach $4 \mathrm{~mm}$.

Between the large zooids are numerous small ones of the normal size and character, which extend up the sides of the rachis between the bases of the leaves.

That the connection of the large ventral zooids with the leaves is of a purely secondary nature is clearly seen by tracing their gradual development in passing upwards from the lower end of the rachis. At their first appearance they are small, identical in all respects with the normal zooids, and quite inde-

* KöLLIKER, Op. cit., pp. 134 and 366.

$\dagger$ RIoHIard, Monografia della famiglia dei Pennatularii, p. 24. 
pendent of the leaves, with which they become connate only after they have attained a considerable size.

The structure of the large zooids, which does not appear to have been examined with any care hitherto, is shown in the series of figures on Plate XXII. Of these fig. 8 represents a median longitudinal section through the whole length of one of the zooids, and through the part of the rachis from which it springs; while figs. 10 to 16 are transverse sections through a zooid at different parts of its length, fig. 10 being near to the apex and fig. 16 passing through the base of attachment of the zooid.

The general anatomy of the large zooid is well shown in fig. 8, from which it will be seen that while agreeing in essential structure with the smaller and more typical zooids, it yet presents some points of special interest.

The zooid is conical in shape, arising by a broad base from the rachis and tapering upwards rather sharply, ending in a pointed apex. As shown in figs. 4 and 8 the zooid does not project horizontally outwards, but obliquely upwards, so that we can distinguish between an inner or axial surface, directed toward the rachis, and an outer or abaxial surface facing outwards.

On the inmer or axial surface, and nearer the base than the apex of the zooid, is the mouth (fig. 8, $n$ ). This leads into the stomodæum $s$, which is lined by columnar ciliated ectoderm cells, the cilia clothing the outer or abaxial wall being of very great length, and forming with the surface of the stomodæum from which they arise the structure which Mr Hickson has recently proposed to speak of as the siphonoglyphe.*

The stomodæum opens below into the general body cavity $h$, which is lined by endoderm, and is in communication with the cavities of the adjacent zooids and with the main lateral canals of the rachis, and so indirectly with the polyps. The stomodæum is attached to the body wall by the usual eight septa, which are well shown in the transverse section (fig. 15). Below the stomodæum the two septa of the inner or axial surface, bounding the axial interseptal cavity, remain of considerable width, and bear at their free edges the two mesenterial filaments (figs. 8 and 16, p), which are very long and much convoluted, and extend down to the bottom of the zooid cavity.

The other six septa become reduced immediately below the stomodæum to very narrow ridges (fig. 16, $m$ ), which disappear altogether a short way lower down.

The body wall of the zooid consists of an outer layer of short columnar ectoderm cells, below which is the firm gelatinous mesoderm. This latter is much thicker on the outer or abaxial surface than it is on the inner or axial, and is strengthened by a great number of large calcareous spicules (figs. 8-16, $i$ ). These spicules are straight rods, thickest in the middle, and with rounded ends ;

* Hickson, on the "Ciliated Groove (Siphonoglyphe) in the Stomodæum of the Alcyonarians," Proc. Roy. Soc., 1883. 
the largest attain a length of $1.6 \mathrm{~mm}$., with a width of $13 \mathrm{~mm}$. In transverse section (figs. 10-16, $i$ ) the spicules are triangular, with rounded angles, and a shallow groove running somewhat obliquely down the middle of each face. They are exceedingly numerous along the whole length of the abaxial surface of the zooid, and are arranged with their long axes parallel, or nearly so, to that of the zooid.

The mesoderm is traversed by a system of irregularly branching nutrient canals continuous with those of the rachis. The muscular system of the body wall of the zooid seems to be completely absent.

The relations of the inter-septal chambers in the part of the zooid above the stomodæum are rather curious. Fig. 14 represents a transverse section through the mouth opening; it shows that at this point only five of the eight interseptal chambers are present, viz., the abaxial, or as it is commonly called, ventral cavity, the two latero-ventral cavities bounding it on either side, and the two lateral cavities; the axial or dorsal and the two latero-dorsal cavities not extending above the mouth. In a section taken a little higher up, through the upper part of the mouth (fig. 13), the two lateral cavities have disappeared, and the mid-ventral and latero-ventral cavities are alone present. Tracing them further up towards the apex of the zooid, we find that all three persist for some distance, but that after a time the middle abaxial or ventral cavity, which has been from the start the smallest ( $c f$. figs. 15 and 14), loses its lumen (fig. 12), and then disappears altogether, the two latero-ventral cavities alone persisting (fig. 11).

Further up still (fig. 10), one of the two latero-ventral cavities disappears and one alone is left, which can be traced nearly, or in some cases quite, up to the apex of the zooid.

The prolongations upwards of the interseptal chambers above the mouth correspond, not to the tentacular cavities of the fully formed polyps, but to the cavities of the calyx processes; and the whole of the part of the large zooid above the mouth is to be regarded as formed by a special unilateral development of the calyx, corresponding at its base to five, and along the greater part of its length to three calyx processes fused together, but with their axial cavities remaining distinct.

That the spine of the large zooid really consists of calyx processes and not of tentacles, is, I think, proved by the perfect continuity between the wall of the zooid itself and the spine; by the unbroken series of exceptionally large spicules extending along the abaxial wall of the whole length of the zooid, including the spine; and by the absolute identity between a transverse section across the upper part of the spine, and one through a calyx process of a normal polyp. This latter point is well shown in figs. 9 and 10, the former being a section of a calyx process, and the latter of the spine of one of the large zooids. 
The agreement will be seen to be absolute, even as regards the actual size and arrangement of the spicules, which in both cases are far larger and more abundant on the abaxial or outer surface than on the axial or inner one. It is also worthy of note, in connection with the point in question, that in the development of the polyps the calyx processes appear earlier than the tentacles (vide fig. 7).

The large zooids of $P$. phosphorea var. aculeata agree, therefore, with the zooids of Pennatulida generally in the complete absence of tentacles, as well as in the absence of reproductive organs and the possession of but two mesenterial filaments. They are peculiar merely in their very great absolute size, and in the prolongation of the abaxial surface to form the spine.

The structure of one of the normal small zooids is shown in fig. 8 , $e$. It will be noticed that here also the mouth, which in the early stages of development is terminal (as shown in the rudimentary zooid between $e$ and the large zooid), becomes thrown over to the axial surface by growth forwards of the abaxial side, which forms a prominence above the mouth clearly comparable to the spine of the larger zooids. The figure shows also that the smaller zooids, like the large ones, possess the clothing of exceptionally long cilia on the abaxial surface of the stomodæum (siphonoglyphe of HICKson).

The small zooid in question (fig. 8,e) is an immature one, as there is as yet no communication between the stomodæum and the body cavity of the zooid; the septa and mesenterial filaments have also not yet appeared.

PANCERI* has described and figured an interesting abnormality occurring in a specimen of $P$. phosphorea, in which four of the latero-ventral zooids, three on the left side of the rachis and one on the right, have the form and structure of fully developed polyps, inserted independently into the rachis, and attaining a length of $10 \mathrm{~mm}$. and a diameter of 1 to $2 \mathrm{~mm}$. In describing this curious modification, PANCERI discusses briefly the mutual relations of polyps and zooids, points out the fundamental and essential correspondence between the two, and infers that the zooids must be regarded as abortive polyps, and that such cases as the one he describes are to be viewed as examples of reversion from the abortive to the fully developed condition.

In this view PANCERI is undoubtedly right. In a colony of individuals formed by continuous gemmation, i.e., by a process of budding in which the several zooids remain organically connected together to form the colony, the several component individuals must be supposed to be primitively all alike and equivalent to one another. Differences in structure and function could clearly only have arisen after the habit of forming colonies had been established for some time. Hence those colonies will be the most primitive in which there is

* PaNceri, "Intorno ad una forma non per anco notata negli zooidi delle pennatule," Rendiconto dell' Academia delle scienze fisiche ê matematiche, pp. 23-28, Napoli, Febbrajo, 1870.

VOL. XXXII. PART I. 
in the adult form the smallest amount of difference between the constituent individuals; while those forms in which this differentiation reaches its greatest development will be the most highly modified forms. These principles are of great importance in framing a scheme of classification of a colonial group such as the Pennatulida, and have not received sufficient attention in the classification at present in use.

In the ordinary $\boldsymbol{P}$. phosphorea the amount of differentiation is comparatively slight, and is brought about in the simplest possible manner ; the asexual zooids being simply arrested at what is merely an early stage of development in the case of the polyps. This is well shown in Pl. XXI. fig. 7, representing a side view of the lower end of the rachis, and showing the early stages of development of the polyps and zooids.

The figure shows that the young polyps $d$ are at first quite independent of one another, and that in their earlier stages they are absolutely identical with the zooids $e$; and that the differences arise from the zooids becoming arrested at this early stage, while the polyps advance further, increase in size, acquire calyx processes $l$, and tentacles $t$, fuse with one another at their bases, so that their further increase in length gives rise to the leaf of the adult, and acquire the full number of mesenterial filaments, and ultimately reproductive organs.

The differentiation is thus of the simplest possible character, the zooids being simply arrested or abortive polyps, whose function is apparently to maintain currents of water circulating throughout the colony, for which purpose they have retained the sole structure peculiar to them-the clothing of exceptionally strong cilia on the abaxial surface of the stomodæum. As the siphonoglyphe is present in the mature polyps of many Alcyonarians, such as Alcyonium (vide Hickson, loc. cit.), it seems certain that in the Pennatulida it is a structure that has been lost by the polyps, but retained by the zooids.

In the variety aculeata differentiation has advanced further; and it is a point of importance to note that the points in which the large zooids differ from the small ones cannot be considered as repetitions of any part of the process by which the polyp is developed from the zooid condition. In the young polyp all the calyx processes arise simultaneously (fig. 7), as do also all the tentacles, so that the asymmetrical development of the calyx in the large zooids must be regarded as peculiar to and acquired by them. The lateral position of the mouth in the large zooids has apparently been acquired independently of and previous to the formation of the calycular spine, inasmuch as it is an equally prominent feature in the normal small zooids (fig. 8, $e$ ).

Judging from their structure, the large zooids would seem to be protective in function, but as to the special circumstances which determine their development in particular forms, we are in complete ignorance. Were our knowledge confined, so far as these forms are concerned, to the "Triton" specimens, we 
should be greatly tempted to suppose that as one set of specimens-the typical $P$. phosphorea-is obtained from a depth of only 40 fathoms, and the other, the variety aculeata, from 555 fathoms, that the structural differences between the two forms may be at any rate in part due to the different external conditions of pressure, \&c.

Although, however, the variety aculeate does appear to occur as a rule in deeper water than the more normal form, yet this rule is not universal, for, as we have seen above, " SARs obtained specimens of aculeata off the Norwegian coast at depths of 30 to 70 fathoms. The determining cause therefore that leads to the production of the variety aculeata must be some other than mere depth, though this would appear to have some influence.

It may be noticed, finally, that the vertical range of $P$. phosphorea, which KöLLIKER† puts at 30 to 300 fathoms, has been nearly doubled by the "Triton" dredgings, which show that the species lives in abundance, though in a rather diminutive form, as low as 555 fathoms.

\section{Sub-section 2. Virgulariece.}

Family 1. Virgularidæ.

Virgularia, Lam.

Virgularia tuberculata, n. sp. (Pl. XXI. figs. 1-3.)

Specific Characters.-Polyps nearly sessile, united at bases in groups of three, the groups alternating on the two sides of the rachis. Calyx completely obliterated when the polyp is fully protruded; calyx margin marked by eight small tubercular processes placed opposite the tentacles. Reproductive organs in the immature leaves at the lower part of the rachis. Stem cylindrical. Colour of colony, yellowish-white. No calcareous spicules in any part.

\section{Habitat.-Station 11.}

Of this species three specimens were obtained, all of which are imperfect. The largest specimen (Pl. XXI. fig. 1) measures $68 \mathrm{~mm}$. in length, and consists of the stalk and lower part of the rachis; its upper end is abruptly truncated, and the upper $10 \mathrm{~mm}$. of the stem are denuded of the fleshy sarcosoma.

The second specimen is similar to the first, but smaller in all its dimensions; it has a total length of $36.4 \mathrm{~mm}$., and consists of the stalk and lower end of rachis, the upper end of which is abruptly truncated.

The third specimen is $46 \mathrm{~mm}$. long, and consists of the middle portion of the rachis of an apparently rather larger specimen than either of the other two; truncated at both ends.

* Supra, p. 123.

$\dagger$ Zool. Chall. Exp., part ii. p. 38, 1880. 
The stalk of the first specimen (Pl. XXI. fig. 18) is cylindrical, with an average diameter of $2 \cdot 1 \mathrm{~mm}$. It presents a slight terminal dilatation at its lower end, and is marked on both dorsal and ventral surfaces by shallow median longitudinal grooves. The stalk has a length of $15 \mathrm{~mm}$, and is continuous above with the rachis, the transition from one to the other being marked by the first appearance of the leaves.

The lower part of the rachis is flattened dorso-ventrally, and has a transverse diameter of $2.6 \mathrm{~mm}$. It is marked by upward continuations of the median dorsal and ventral grooves of the stalk.

As we pass from the region with inmature leaves to the part of the rachis bearing fully developed polyps, the rachis gradually becomes reduced in width, and in the upper part, where the polyps have attained their full size, it becomes cylindrical, with a diameter in the first specimen of $0.5 \mathrm{~mm}$, forming in fact a very thin fleshy investment to the stem.

The stem is cylindrical at its upper end, with a diameter of $0.4 \mathrm{~mm}$; it remains of nearly uniform size throughout the whole length of the rachis, but tapers gradually as it passes down the stalk. It is of considerable brittleness, especially in its upper part.

The polyps commence in the lower part of the rachis as small transverse ridges placed very close together, the first $6 \mathrm{~mm}$. of the rachis having 20 of these ridges on each side. Passing upwards, the ridges become more prominent, wider, and situated further apart, each being divided at its free edge into three polyps.

Of the three polyps of a ridge, the dorsal one is from the start the smallest of the three, and the ventral one the largest; and these proportions are retained throughout.

As the polyps get larger, the groups move further and further apart, until the interval between successive groups on the same side of the rachis is about $3 \mathrm{~mm}$., which appears to be the limiting distance.

The ridges on the lower part of the rachis are so placed that while the dorsal polyps of the ridges of the two sides are almost in contact with one another in the mid-dorsal line, the ventral polyps are separated from one another by nearly the whole width of the ventral surface of the rachis, an arrangement which persists also in the fully formed polyps (fig. 2).

The groups of polyps are from the first placed, not opposite one another, but alternately, as shown in figs. 1 and 2 , the right hand group being a little in advance of the left one.

The polyps of each fully developed group are almost completely independent of one another, their bases alone being united together, so that it is hardly possible to speak of distinct leaves. The inclusion of the species in the genus Virgularia is fully justified, however, by the general mode of development of 
the polyps, especially the simultaneous appearance of the component polyps of a group ; by the position of the reproductive organs in the immature polyps, the proportions of the stem at different heights, and by the existence of such forms as Virgularia bromleyi* in which the separation of the polyps is not carried quite so far as in $V$. tuberculata. From $V$. bromleyi, the new species is distinguished at once by the absence of calcareous spicules, and the presence of the tubercles marking the calyx margin.

Concerning the development of the polyps, it can be ascertained by examination of the immature polyps at the lower end of the rachis, that the stomodæum arises as usual as an involution of the ectoderm, appearing before the tentacles, which latter all develop simultaneously. In the early stages of development one tentacle is very commonly rather larger than the other seven, but whether this is an accidental feature or not I have been unable to determine, nor have I detected any constancy of position of the larger tentacle. In each group the ventral polyp is always the furthest developed, and the dorsal one the least so.

In the smaller of the two specimens in which the stalk is perfect, the change from the immature to the fully developed polyps is a very abrupt. one ; not gradual as in the larger specimen figured (Pl. XXI. fig. 1). The stalk in this smaller specimen is $8 \mathrm{~mm}$. long; the first $4 \mathrm{~mm}$. of the rachis bear immature leaves only, and above this point the fully formed polyps commence abruptly.

The fully expanded polyp (fig. 2) measures about $2.5 \mathrm{~mm}$. in length, of which the tentacles form rather more than half; its width is about $0.2 \mathrm{~mm}$. Opposite the insertion of the polyp, and for some little distance above and below it, the sarcosoma of the rachis is markedly thickened (fig. 2), giving the rachis at these places a quadrangular shape. The boundary line between the body of the polyp and the tentacles is indicated in the fully expanded polyp by a row of eight small knob-like processes placed opposite the tentacles (fig. 2). These processes are hollow, and consist of all three layers of the body wallectoderm, mesoderm, and endoderm; they appear to correspond to the calyx processes of other Pennatulida.

When the polyp is retracted, as in the lower specimens of fig. 2, these processes mark the line of invagination, and become much more conspicuous, appearing as knobs placed round the edge of the calyx.

In the "Triton" specimens, retraction of the polyp is never carried further than is shown in fig. 2, the fully retracted polyp being about half the length of the fully expanded one. Retraction is probably effected slowly, as the great majority of polyps have died in an almost completely expanded state.

The tentacles are rather longer than the body of the polyp; are pinnated as shown in fig. 2, and present no special features of importance.

\footnotetext{
* KöLLIKER, Zool. Chall. Exp., part ii. p. 9, 1880.
} 
The anatomy of the polyp, so far as I have had the chance of investigating it, agrees with that of other Virgularice. The reproductive organs, as in Virgularioe generally, are contained, not in the mature polyps, but in the immature ones at the lower end of the rachis.

The large specimen (fig. 1) is a male, and a small part of the rachis removed from a point $22 \mathrm{~mm}$. from the lower end of the stalk, showed the mature male organs or spermatospheres. These (fig. 3) have the typical structure of the male organs of Pennatulids. They are oval or spherical bodies, the largest of which have a diameter of $0.38 \mathrm{~mm}$." Each is enclosed in a very thin capsule, the contents of which are a mass of very minute brightly refracting bodies-the heads of the spermatozoa; these are more closely packed at the periphery than in the centre, where a number of fine radiating filaments can be seen, which are probably the spermatozoa tails.

The smaller specimen, in which the lower end of the rachis is present, was also examined for reproductive organs, but none were found. The third specimen, consisting of the middle part alone of the rachis, is of course devoid of reproductive organs.

This specialisation of the reproductive organs to the immature polyps is undoubtedly a sign of considerable differentiation, and marks Virgularia as a less primitive genus than such a form as Pennatula. For while in the latter the component individuals of the colony are of two kinds only-zooids and polyps-in Virgularia they are of three kinds-zooids, nutrient individuals, and reproductive individuals. Whether all the immature polyps ultimately develop into mature ones is uncertain ; probably not, inasmuch as all recorded specimens of Virgularia have immature polyps at the lower end of the rachis. The abrupt transition from the immature to the mature polyps described above as occurring in the second example of $V$. tuberculato, may perhaps indicate the existence of a sharp line of demarcation between the sexual and the nutrient individuals.

Whether zooids are present or not in $V$. tuberculata, I have been unable to determine with certainty without destroying the specimens. Certain very small knob-like projections on the rachis near the base of the polyps may perhaps prove to be zooids; if so, they are in an exceedingly rudimentary condition.

As noticed above, all three specimens of $V$. tuberculata are imperfect, and their imperfection is of some interest, inasmuch as it is very characteristic of dredged specimens of Virgularia generally. Of the type species, V. mirabilis, a perfect specimen has never yet been seen, all the specimens recorded being fractured either at one or both ends. The lower ends or stalks are occasionally found perfect, but the upper end never, the only known exception being a single specimen in the Glasgow Museum.

The cause of this mutilation has been elsewhere discussed. It has been 
suggested * that the lower fracture, which usually occurs about the junction of stalk and rachis, i.e., about the point of emergence from the mud of the sea bottom, is caused by the dredge at the rnoment of capture; while the upper fracture is almost certainly effected quite independently of the dredge, and is perhaps due to the tops being browsed on as food by other animals. The great brittleness of the calcareous stem probably accounts for the readiness with which the specimens become broken, and the fact that of the three specimens of $V$. tuberculata, the one brought up by the dredge is broken at both ends, while the two taken with the trawl have their lower ends entire,speaks strongly in favour of the correctness of the first part of the above explanation.

The measurements of the three specimens are as follows :-

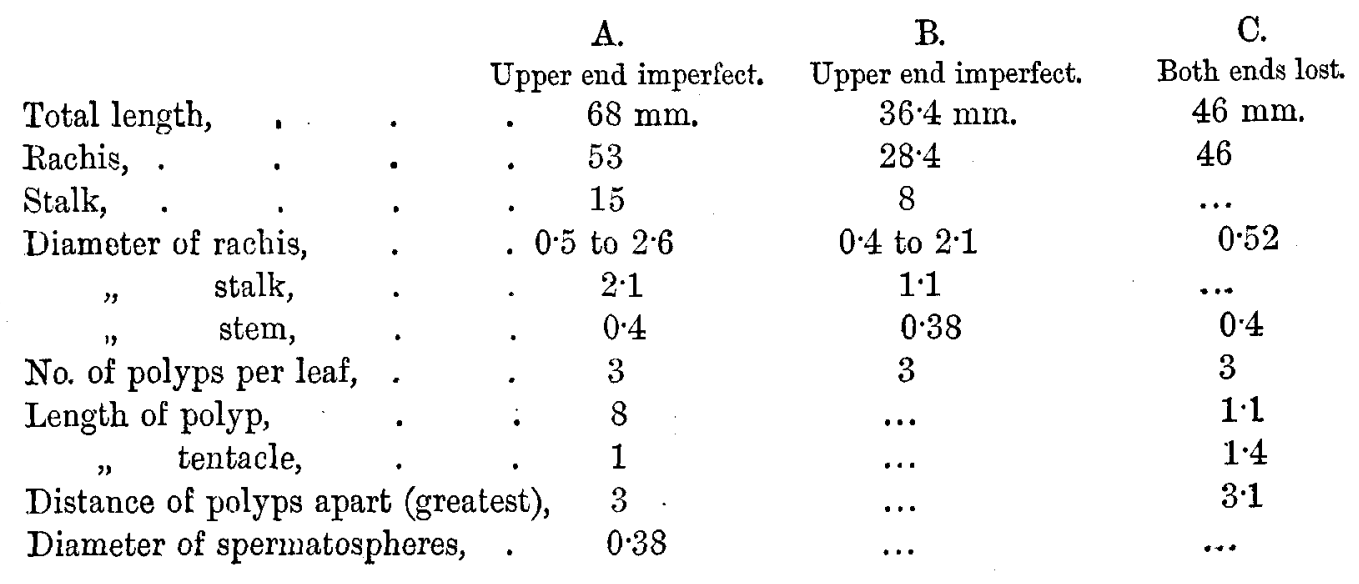

Fanily 2. Stylatulidæ.

Dübenia, Kor. and Dan.

Dübenia abyssicola var. smaragdina (Kor. and Dan.). (Pl. XXIII. figs. 17-21.)

A single fragment of this species was obtained from Station 11 at a depth of 555 fathoms. The specimen, which is imperfect at both ends, and has a total length of $61 \mathrm{~mm}$., is represented from the ventral surface three times the natural size in Pl. XXIII. fig. 17 ; while figs. 18 and 19 represent on a larger scale portions of the rachis as seen from the lateral and dorsal surfaces respectively.

Inasmuch as the sole description that has yet appeared of this very beautiful form is the extremely short and imperfect account given by KorEN and Danielssen, $\uparrow$ I have thought it well to investigate and describe the "Triton" specimen as fully as could be done without injury to it.

The rachis (figs. 17, 18, and 19) is cylindrical, and only slightly exceeds in diameter the cylindrical stem by which it is traversed throughout its length. At the upper end of the specimen the stem projects bare for a length of about

* Vide Report on the Oban Pennatulida, by A. M. Marshall and W. P. Marshall, 1882, pp. 57-60.

$\dagger$ Fauna littoralis Norvegice, part iii. p. 26, and pl. x. figs. 7 and 8, 1877. 
$3 \mathrm{~mm}$. above the uppermost polyps, ending in an abruptly truncated and evidently broken extremity. At the lower end the fracture appears to have occurred about the junction of stalk and rachis, but the fleshy sarcosoma has been stripped off the lowermost $8 \mathrm{~mm}$., leaving this part of the stem bare, and rendering it impossible to localise exactly the seat of fracture. The stem is quite as brittle as that of Virgularia, so that there can be little doubt that the cause of fracture is the same in the two cases.

The entire specimen is of a pale yellowish-white colour, but has become a good deal discoloured in parts, apparently from the action of the spirit in which it was preserved.

The polyps (figs. 17, 18, and 19) are arranged in pairs along the sides of the rachis, each pair being embraced at its base by the fan-shaped plate of calcareous spicules $k$, so characteristic of the family Stylatulide. The pairs of polyps are not inserted opposite one another, nor do they strictly alternate; but those of the left side are situated a little further forward, nearer the upper end of the rachis, than the corresponding pairs of the right side.

The intervals between successive pairs of polyps on the same side of the rachis (fig. 17) gradually increase in passing upwards. At the lower end of the specimen the successive pairs are almost in contact with one another, but in passing upwards they move further and further apart, the intervals attaining a maximum a short way below the upper end of the specimen, above which point they decrease slightly, the polyps themselves also becoming smaller.

The characters and relations of the fan-shaped spicular plates are well shown in figs. 18 and 19. Each plate is triangular, with the apex directed downwards and inserted into the rachis, and with its free upper edge surrounding the base of the pair of polyps to which it belongs. The plate is formed by the fusion of a number of radiately arranged spicules, of which the more deeply placed ones are smaller and completely fused together, while some of the more superficial ones are much larger, and not so closely fused. One of these large spicules is represented in fig. 21 ; it is widest near its lower end, and gradually tapers upwards to a point, which (figs. 18 and 19) projects freely for a short distance above the upper edge of the plate. These large spicules may attain a length of $2.3 \mathrm{~mm}$. and width of $0.15 \mathrm{~mm}$. From the apex of the spicular plate a number of smaller rod-like spicules (fig. 18) are continued for a variable distance down the rachis.

The two polyps of each pair have their bases, which are covered by the spicular plate, fused together so as to form a rudimentary leaf. Above the level of the top of the spicular plate they are, however, completely free from one another. Of the two polyps, the dorsal one is always slightly smaller than the ventral one in accordance with the general rule among Pennatulida. The dorsal polyps of corresponding pairs are separated from one another by but a 
slight interval (fig. 19), while the ventral polyps are separated by the whole width of the ventral surface of the rachis.

The polyps are retractile, and the extremes of contraction and expansion are represented in the two polyps of the upper pair in fig. 18. As the figure shows there is no calyx formed during retraction, and the tentacles appear to contract to a less extent than the bodies of the polyps. As in the case of Virgularia tuberculata, the fact that the majority of the polyps have died in an expanded or half-expanded condition may be taken as evidence that contraction is effected slowly.

Each tentacle is supported on its outer or aboral surface by a strong rib of calcareous spicules shown on a larger scale in fig. 20. These spicules are placed for the most part obliquely, running upwards and outwards; they have an average length of $0.13 \mathrm{~mm}$. and diameter of $0.02 \mathrm{~mm}$. They do not extend into the pinnules.

At intervals along the body walls of the polyps spicules are found similar to those of the rachis, but rather smaller and less abundant.

Concerning the reproductive organs I have no observations. According to KoneN and DANielssen, ${ }^{*}$ these are normally situated in the body cavities of the fully developed polyps in the genus Dübenia; but a large polyp from the middle of the colony, which I opened for the purpose, had no trace of reproductive organs.

The zooids are few in number, and very small and inconspicuous. They occur (fig. 19,e) as small rounded swellings on the dorsal surface between the pairs of polyps, and also on the sides of the rachis just above the polyps.

The genus Dübenia was established by Konen and Danielssen in 1874, + and was at first named Batea, but that name being already appropriated for a genus of Crustacea, it was changed in 1877 to Dïbenia. It includes those members of the family Stylatulidoe in which the polyps, though fused at their bases, do not form distinct leaves, the fusion not extending above the calcareous fanshaped spicular plate. The validity of the genus has been questioned by VerRILL and by Richiardi, but is accepted by KöLliker in bis Report on the "Challenger" Pennatulida, and may be considered as established.

The "Triton" specimen has all the characters of Dübenia abyssicola var. smaragdina, as defined by Konen and DANIELSSEN. $f$ This variety differs from the typical $D$. abyssicola in its more slender form, in its pale colour, and in having the polyps in groups of two instead of three or more. KoneN and DANIELSSEN express a doubt as to whether it should not be considered a distinct species rather than a mere variety, a doubt which I must share without

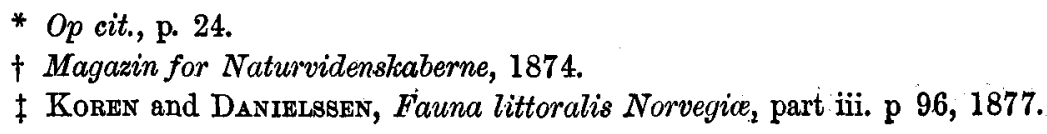


attempting to remove, as I have had no opportunity of examining specimens of the typical $D$. abyssicola.

The variety smaragdina has hitherto only been recorded from the Ramsfjord close to Alvorströmmen, two miles from Bergen, where it was found "at a depth of 100 to 120 fathoms on a clayey sand bottom," in company with the typical $D$. abyssicola, but in smaller numbers.

The measurements of the "Triton" specimen are as follows; tbose of two specimens described by Koren and DANIELSSEN being given for the sake of comparison:-

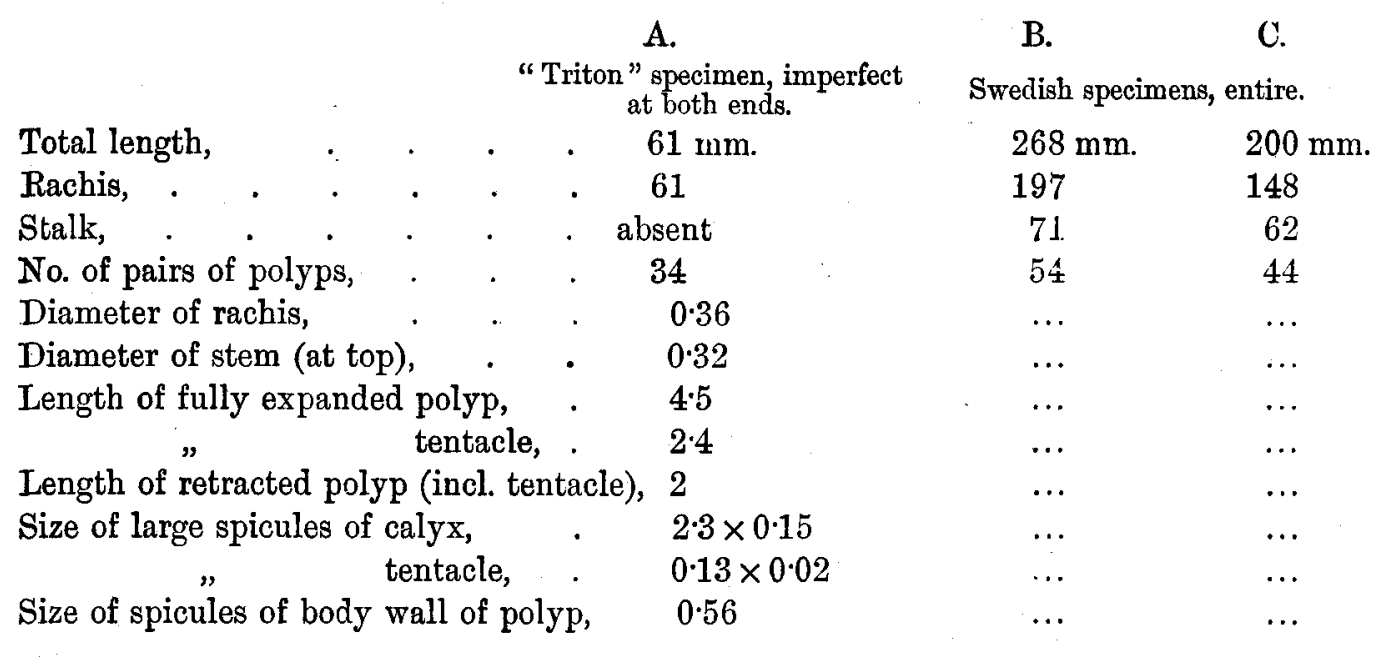

\section{Section II. SpICATa.}

Sub-section 1. Funiculinece.

Family 1. Funiculinidæ.

Funiculina, Lam.

Funiculina quadrangularis, Pall. (PI. XXIII. fig. 22.)

Ten fragments of this species were obtained by the "Triton" in Loch Linnhe, off Castle Walker, in 35 to 37 fathoms of water, and at a distance of $3 \frac{1}{4}$ miles from the shore.

All the specimens are small and imperfect. Two of them, of 9.4 and $12.5 \mathrm{~cm}$. length respectively, have the stalks perfect, and are broken short above at the lower part of the rachis. The remainder are all mere fragments broken at both ends, and varying in length from 5 to $34 \mathrm{~cm}$.

None of the specimens have the upper ends perfect, a very unusual circumstance with this species, which is usually obtained in perfect condition. The specimens have, however, evidently been roughly handled, and were probably damaged at the time of capture. 
All the fragments belong to small and young specimens. Inasmuch as $F$. quadrangularis is found at other parts of Loch Linnhe in great profusion and of large size, specimens having been obtained up to $162 \mathrm{~cm}$. in length, it would appear that the locality from which the "Triton" specimens were obtained is not one favourable to this species.

The portion of rachis of one of the young specimens drawn in fig. 22 shows some points of interest. In the first place, it will be noticed that the calcareous spicules, which in $F$. quadrangularis are usually confined to the calyx, here extend down the whole length of the polyps along the lines of attachment of the septa. These spicules, which also occur in the rachis, though in smaller numbers, have an average length of $1.7 \mathrm{~mm}$. The unusual abundance of these spicules, and their presence in such young specimens, are points of interest.

The middle polyp of the figure is shown in a condition of extreme contraction; the tentacles being completely withdrawn within the calyx, the processes of which meet one another so as to form an acutely pointed cone. This figure agrees very closely with one given by KöLLIKER, * the accuracy of which has been doubted, owing to the shape being so very unlike that of the expanded or halfexpanded polyp, and the apparently exaggerated length of the calyx processes.

Fig. 22 shows also the gradual increase in size of the polyps in passing from the dorsal (right-hand surface in the figure) to the lateral surface; also the entirely independent insertion of polyps and zooids-a primitive feature; and the total absence of distinction between the young polyps and the zooids; also the quadrangular shape of the stem.

Sub-section 2. Junciformes.

Family 1. Kophobelemnonidæ.

Kophobelemnon, Asbjörnsen.

Kophobelemnon stelliferum var. durum (Köll.). (Pl. XXIV. figs. 23-28.)

Thirty-three entire specimens of this species and seven heads (the upper polyp-bearing part of the rachis) were obtained, one of these being from the "Knight Errant" collection, the remainder from the "Triton" one. They were dredged at four different localities, Stations 6, 8, 10, and 11, and at depths varying from 516 to 640 fathoms.

K. stelliferum was first found by O. F. MüLLER in 1775, near Dröbak, in the Christianiafjord, and described by him in the Zoologia Danica, under the name Pennatula stellifera. It has been dredged in various parts of the Christiania fjord by Loven and by AsBJöRNSEn, + the latter of whom obtained it in con-

* KöLLIKER, op. cit., pl. xvii. fig. 153.

$\dagger$ Asbü̈rnsen, "Beskrivelse over Kophobelemnon Mülleri," Fauna littoralis Norvegice, Andet Hefte, pp. 81-85, and Tab. 10, figs. 1-8, 1856 . 
siderable numbers at a depth of about 40 fathoms, and of sizes varying from $20 \mathrm{~mm}$. long, with only a single polyp, to $125 \mathrm{~mm}$. long, with 24 polyps.

A single specimen was obtained by Panceri from the Bay of Naples,* and during the "Porcupine" expedition two specimens were obtained by CarPenter and Wyville Thomson ${ }^{+}$off the N.W. coast of Scotland,-one in $59^{\circ} 41^{\prime} \mathrm{N}$., and $70^{\circ} 34^{\prime} \mathrm{W}$., at a depth of 458 fathoms, the other in $59^{\circ} 34^{\prime} \mathrm{N}$., and $7^{\circ} 18^{\prime}$ W., and at 542 fathoms depth.

External Characters.-The "Triton" specimens vary much in size, and in the number and arrangement of the polyps. The smallest specimen is $26 \mathrm{~mm}$. long, and has only two polyps; the largest specimen in the collection, the single specimen obtained by the "Knight Errant," is $88 \mathrm{~mm}$. long, and bears 18 polyps.

The general appearance of one of the average specimens of the "Triton" collection is well shown in Pl. XXIV. fig. 23 ; the specimen being drawn from the dorsal surface, double the natural size.

The rachis, which is somewhat club-shaped, is widest a short distance below its upper end, from which point it tapers upwards to a blunt point. It bears on its dorsal and lateral surfaces the polyps, which are few in number, and of large size. Between the polyps the surface of the rachis is studded on all sides with zooids, excepting a short tract immediately below each of the polyps, which is destitute of zooids.

The stalk (fig. 23, $b$ ), which forms rather more than half the entire length of the colony, and which is distinguished from the rachis by bearing no zooids, is oval in section, as shown in fig. 27 , and of tolerably uniform size along its whole length, except at its lower end, which presents a terminal thin-walled dilatation.

The arrangement of the polyps differs a good deal in different specimens, and it is difficult to make out any definite system. In all cases the uppermost polyps, those nearest the top of the rachis, are the largest, and the lowest ones the smallest. The most usual arrangement is that shown in fig. 23. Here there are six fully developed polyps arranged in two sets, an upper and a lower one, each of three polyps. Of these three, one is inserted in the dorsal surface of the rachis very close to the mid-dorsal line, or actually in it, while the other two are inserted on the sides of the rachis a little way below the dorsal polyp, and not quite opposite one another, the right hand polyp being as a rule a little above the left hand one. The three polyps of each set are of about equal size, but those of the upper set are much larger than those of the lower set. Below the lower set can be seen in many specimens, as in the one figured, a third set of

* Panjoeri, "Intorno a due Pennatularii l'uno non per anco trovato nel Mediterraneo, l'altro nuovo del nostro golfo," Rendiconto dell' Academia delle scienze fisiche é matematiche, Napoli, Giugno, 1871.

† Vide KöLLIRER, op. cit., p. 306. 
very small and as yet rudimentary polyps, arranged in a manner exactly corresponding to the upper sets.

It is clear that this arrangement might also be described by saying that the polyps are arranged in three longitudinal series, one dorsal and two lateral, the members of each series decreasing in size from above downwards, and this is indeed the method usually adopted. I am disposed, however, to prefer the former mode of description, because it seems to me from an examination of a number of specimens, that the three polyps of each set arise simultaneously, or very nearly so, the dorsal polyps being often a little ahead of the lateral ones, and the right lateral polyps appearing sometimes a little earlier than the left ones.

There appears, indeed, to be a fair amount of constancy in the arrangement and order of appearance of the polyps. Of twelve specimens, four had 3 polyps only, which were clearly the three of the upper set ; five had 6 polyps arranged as in fig. 23 ; one had 4 polyps, i.e., the 3 of the upper set and the second dorsal one; and the other two had 4 and 5 polyps respectively arranged in an irregular manner. In specimens with a larger number of polyps than six, it is very difficult to make out any definite plan of arrangement.

Structure of Polyps. - This has been very fully described by KöLLIKER, ${ }^{*}$ and will not be considered here in any detail. The main points are shown in the figures 24 to 28. The mesoderm is everywhere, both in stalk, rachis, and polyps, of considerable thickness, and has an immense number of calcareous spicules imbedded in it (figs. 27, 28). Each tentacle (figs. 24 and 25) has along its outer surface a prominent rib, made up of closely packed spicules, while smaller ones extend along the pinnules, as first noticed by PANCERI.

The spicules of the tentacular rib, which may attain a size of 0.66 by 0.11 $\mathrm{mm}$., are of the shape shown in fig. 26, and in transverse section in fig. 25.

The polyps project from the rachis nearly at right angles, as shown in fig. 23, and the polyp cavities on reaching the rachis do not stop, but bending down at right angles to their former course, are continued for some distance down the rachis, ending blindly below; the lower part of the stomodæum, and the whole of the organs below the stomodæum being thus contained within the rachis. The greater part of the thickness of the rachis is, in fact, made up of these lower ends of the polyps, which in a transverse section of the rachis will be seen cut at various levels.

Fig. 28 represents such a section. On the left side it cuts one of the lateral polyps longitudinally and horizontally ( $c f$. fig. 13$)$; on the right side it cuts the corresponding polyp of that side lower down, the section passing transversely through the lower part of the stomodæum. The dorsal polyp of the set is cut at a still lower level, the section passing through the two long mesenterial filaments and the ova.

* Op. cit., pp. 297-304. 
The section also shows four zooids cut, like the polyps, in different planes and at different levels.

Plane of Symmetry.-Each polyp of a Pennatulid colony can be divided longitudinally into two perfectly similar halves by one plane only, which is spoken of as the plane of symmetry. This plane passes between the two long mesenterial filaments, bisecting the septal chamber bounded by the two septa which bear these filaments; it also bisects the septal chamber immediately opposite to this one, and passes along the long axis of the stomodæum, which in transverse section (fig. $28, s$ ) is oval, not circular in shape. In Kophobelemnon this plane of symmetry of each polyp has a very definite relation to the rachis. The plane is a vertical one, and is perpendicular to the surface of the rachis to which the polyp is attached, so that if prolonged it would pass through the centre of the calcareous axis or stem. These relations will become more obvious from an inspection of fig. 28. In the case of all three polyps shown in this figure, the planes of symmetry, being vertical when the specimen is placed upright in its natural position, will be at right angles to the plane of the paper. In the case of the dorsal polyp the plane of symmetry must pass through the centre of the polyp cavity, and must also (by definition) pass midway between the two long mesenterial filaments $p$; it is obvious from this figure that this plane, if prolonged, will pass through the centre of the calcareous stem $c$.

So also in the case of the right hand polyp of the figure. In order to divide the retractor muscles $r m$ symmetrically, it is clear that the plane of symmetry must bisect the septal chamber next to the stem $c$, and also the chamber immediately opposite to this one; such a plane will pass along the longer axis of the stomodæum $s$, and will, if prolonged, pass through the centre of the stem $c$.

So with all the other polyps, the plane of symmetry will always be a vertical one, will be at right angles to the surface of the rachis at the point of insertion of the polyp, and will, if prolonged, pass through the centre of the calcareous stem.

It is further evident from fig. 28 that the two long mesenterial filaments are on the side of the polyp next to the stem, so that the surface of the polyp which, when the polyp becomes free from the rachis ( $c f$. fig. 23), is continuous with its upper surface, may conveniently be called the axial surface; while the opposite surface, which is furthest from the stem, and which is continuous with the lower surface of the polyp when this becomes free from the rachis, may be called the abaxial surface.

I have already used the terms axial and abaxial when describing the surfaces of the Pennatula zooids, ${ }^{*}$ and have done so in exactly the same sense

$$
\text { * Supra, p. } 125 .
$$


as that here proposed, the axial surface being that which bears the long mesenterial filaments. As these words express a real and an important relation, they would appear preferable to the very misleading terms dorsal and ventral, which are commonly employed to denote the surfaces in question.

The plane of symmetry of the zooids obeys exactly the same laws as that of the polyps, the mesenterial filaments being placed on the axial wall.

Concerning the arrangement of the zooids on the rachis, it will be seen from fig. 28 that the reason of the existence of a short tract devoid of zooids immediately below each polyp is that this tract is really part of the abaxial wall of the polyp; and as the zooids are developed on the rachis itself and not on the polyps, there can clearly be no zooids on these tracts.

Retraction of Polyps.-In spite of the great rigidity of the wall both of the polyp itself and its tentacles, due to the enormous number of spicules contained in it, the polyps can, as shown on the right-hand side of fig. 23 , be withdrawn almost completely into the rachis, the tentacles entirely disappearing from sight in the fully retracted state. During the process of retraction the body wall of the polyp is thrown into transverse folds, and one specially deep fold at the junction of body and tentacles (vide the left-hand polyp of fig. 28) corresponds to the calyx of other Pennatulida.

Structure of Stalk.-This is well shown in fig. 27, representing a transverse section taken about the middle of its length. The mesoderm is of great thickness, and is divided into inner and outer zones by the well-developed layer of longitudinal muscles $l m$, which forms a deeply corrugated sheath extending round the whole stalk. Of the two zones the outer one is very richly studded with calcareous spicules $i$, crossing one another in all possible directions; while the inner zone is devoid of spicules, and is traversed by a dense network of nutrient canals. The stem $c$ is quadrangular, with rounded angles and grooved lateral surfaces. In the rachis, as we have seen (fig. 28), the stem is cylindrical; but this change in shape is by no means exceptional, occurring in Pennatula and several other genera, as well as in Kophobelemnon.

The stem is invested by a mesodermal sheath, which is prolonged outwards to the body wall as four vertical septa, which separate from one another the four main longitudinal canals of the stalk, of which the dorsal $d c$, and ventral $v c$, are considerably larger than the lateral ones $l c$. If these canals, which are lined by endoderm, be traced upwards towards the rachis, the two lateral ones are soon found to disappear; the dorsal one extends a short distance up the rachis, and then in its turn disappears, while the ventral one (fig. 28, vc) persists of considerable size throughout the whole length of the rachis.

Of Kophobelemnon stelliferum KöLLIKER* distinguished at first two varieties, which he named mollis and dura respectively, the difference consisting chiefly

* KöLLIKER, op. cit., p. 305. 
in the greater number and size of the spicules of the latter, which reach in the tentacles a length of from 0.64 to $0.89 \mathrm{~mm}$. and width of 0.09 to $0.12 \mathrm{~mm}$. The muscular layers are also far less strongly developed in the var. dura than in var. mollis.

At a later period* he described a specimen from the Atlantic at a depth of 690 fathoms, which was in all its characters intermediate between the two other forms, and seemed to prove them to be merely varieties, and not, as once supposed, specifically distinct.

The "Triton" specimens belong clearly to the variety dura, though they differ a good deal among themselves as to the size of the spicules. The single specimen from the "Knight Errant" collection has much smaller spicules than any of the others, and is to be referred to the variety intermedia.

The following table gives the measurements of the "Knight Errant" specimen and of one of the typical "Triton" specimens :-

A.

\begin{tabular}{|c|c|}
\hline & $\begin{array}{c}\text { Var. intermedia } \\
\text { from "Knight Errant." }\end{array}$ \\
\hline Total length, & . $\quad 82 \mathrm{~mm}$ \\
\hline Length of rachis, & 43.5 \\
\hline " stalk, & $38 \cdot 6$ (broken at lower end) \\
\hline No. of polyps, . & 18 \\
\hline Size of spicules (largest) & $0.31 \times 0.018$ \\
\hline
\end{tabular}

B.

Var. dura from "Triton."

$45 \mathrm{~mm}$.

21

24

6

$0.66 \times 0.11$

All the specimens of $K$. stelliferum were encrusted rather thickly with sand, which adhered somewhat firmly to the ectoderm, and doubtless acted in part as a protective envelope. The internal cavities, both stomodæum, body cavity, and tentacular cavities, also contained large quantities of sand, which rendered the preparation of sections a matter of some difficulty. Whether this indicates a habit of retraction into the sand in which they live planted by their stalks, or whether the sand is purposely swallowed for the sake of food matters that may be mixed with it, I have had no opportunity of determining.

Family 2. Umbellulidæ.

\section{Umbellula, Lam.}

Umbellula gracilis, n. sp. (P1. XXV. figs. 29-35.)

Specific Characters.-Distinctly bilateral. Polyps forming a cluster on the upper end of a club-shaped rachis ; greyish in colour with dark reddish-brown tentacles. Stalk long, very slender and exceedingly flexible; ending below in a dilated vesicular portion. Zooids numerous on the rachis between the polyps,

$$
\text { * Op. cit., p. } 320 .
$$


and extending a short distance below them; zooids of upper part of rachis much the largest, and each provided with a tentacle bearing a double row of pinnules ; zooids of lower part of rachis are smaller,- they may have tentacles, but these do not bear more than a single pinnule. Stem cylindrical along the greater part of its length, becoming quadrangular in the terminal dilated part. No calcareous spicules at any part of the colony.

Habitat.-Station 11 ; depth 555 fathoms.

External Characters.-A single specimen of this species was obtained with the trawl. This specimen, which is in perfect condition, is represented of the natural size, and from the dorsal surface in Pl. XXV. fig. 29. It has a total length of $290 \mathrm{~mm}$., of which the upper $26 \mathrm{~mm}$. are expanded to form the club-shaped rachis. This ends above in a blunt point (fig. 30), and is widest about the middle of its length, where it measures $6 \mathrm{~mm}$. from side to side, and $5 \mathrm{~mm}$. from the dorsal to the ventral surface.

The rachis bears the polyps on the upper two-thirds of its length, and below the lowest polyp tapers somewhat rapidly, and passes without any sharp line of demarcation into the stalk.

The stalk is cylindrical and very slender, with a diameter about the middle of its length of $0.8 \mathrm{~mm}$. At its lower end it presents a distinct enlargement, $35 \mathrm{~mm}$. long and $3.5 \mathrm{~mm}$. in diameter. For the greater part of its length the stalk is extremely flexible, so much so that it can readily be coiled in circles of $5 \mathrm{~mm}$. diameter without the slightest danger of breaking.

The stem or calcareous axis is cylindrical along the greater part of the length of the stalk, with an average diameter of $0.5 \mathrm{~mm}$. Shortly before reaching the terminal dilatation of the stalk the stem enlarges somewhat suddenly to $0.9 \mathrm{~mm}$. in diameter, becoming at the same time quadrangular in shape, and very much more rigid than in the upper part. In the terminal dilatation it gradually tapers towards the lower end.

The polyps, which are confined to the upper $18 \mathrm{~mm}$. of the rachis (figs. 29 and 30) are 13 in number, and gradually increase in size from above downwards. They are inserted on all sides of the rachis, with the exception of a narrow strip $1.5 \mathrm{~mm}$. wide along the mid-ventral surface (fig. 30 ), and even this is somewhat encroached upon by the lowest polyps.

It is difficult to make out any definite plan of arrangement of the polyps. Commencing at the top, the first polyp, which is the smallest of the lot, is inserted in the left latero-dorsal surface just below the apex. The second polyp is placed on the right latero-dorsal surface, a little way below the first. Then comes a rather irregular whorl of six polyps, of which two are dorsal, two lateral, and two latero-ventral; and finally a lower whorl of five polyps, the largest of all, of which one is mid-dorsal, two lateral, and two latero-ventral, the left one of the last pair almost reaching the mid-ventral line.

voL. XXXII. PART I. 
The body of the polyp is greyish in colour, and from 10 to $15 \mathrm{~mm}$. in length. It is widest at its base $-4 \mathrm{~mm}$. in the larger polyps, and gradually narrows in its upper third to $2.5 \mathrm{~mm}$. The upper part is marked by very distinct longitudinal grooves opposite the septal attachments, and is also slightly corrugated transversely.

The tentacles are of a dark reddish-brown colour, and of about the same length as the polyp body. Each is fringed by a double row of pinnules, which exhibit an irregular alternation of larger and smaller ones (fig. 31); the larger pinnules being inserted rather nearer the inner or oral surface of the tentacle than the small ones. LINDAHL * has directed special attention to this inequality of the pinnules in the case of $U$. Lindahli (Köll.)t, where it appears to be much more marked than in $U$. gracilis.

The polyps and tentacles are non-retractile, or can at most be withdrawn to a very slight extent, and there is no trace of a calyx.

Structure of Polyp.-One of the polyps was removed for the sake of studying its structure, and cut into a series of transverse sections. The anatomy presents no points of special importance. The body wall is of only moderate thickness, the body cavity and tentacular cavities being of large size. As in Kophobelemnon the polyp cavities are prolonged into the rachis, but a larger proportion of the polyp is free than in this genus; the stomodæum and upper part of the mesenterial filaments being contained within the free part of the polyp, and the reproductive organs and lower part of the mesenterial filaments being alone situated within the rachis.

The plane of symmetry in the case of the one polyp examined, and presumably in the others as well, obeys the same laws that have been found above to apply to Kophobelemnon and Pennatula, i.e., it is vertical and at right angles to the surface of the rachis at the point of insertion of the polyp. The axial surface of the polyp, moreover, is that which bears the two long mesenterial filaments.

The single specimen obtained is a female, and the arrangement of the reproductive organs is the same as in other Pennatulida, the ovaries being the free edges of the six septa which bear, higher up, the six short mesenterial filaments. Fig. 34 represents a section of one of these fertile septa and of the part of the body wall from which it springs. The figure shows the largely developed retractor muscle of the polyp $\mathrm{rm}$, and at the edge of the septum ova in various stages of development, each with a large nucleus and nucleolus, and invested in a distinct epithelial capsule. The ripe ova have a diameter of $0.1 \mathrm{~mm}$.

* Lindaht, "Om Pennatulid-slägtet Umbellula," Kongl. Svenska Vetenskaps-Akademiens Handlingar, Bd. xiii. No. 3, Stockholm, 1874.

$\dagger$ KöLliker, Die Pennatulide Umbellula, Wurzburg, 1875. KöLLIKER proposes to group together LINDAHL's $U$. miniacea and $U$. pallida under the name $U$. lindahli. 
The specimen being in excellent histological condition, I have been enabled to make some observations on the development of the ova. Fig. 35 represents a transverse section through one of the ovigerous septa close to its free inner edge. The septum is seen to consist of a central mesodermal lamella $x$, clothed on each side by a thick layer of endodermal cells $y$. Of these cells the superficial ones form a layer of short columnar or cubical cells, while the remainder of the endoderm consists of larger cells of irregular polygonal shape, closely packed together, with large granular but rather ill-defined nuclei and granular protoplasm.

Among these cells certain ones are conspicuous by their larger size and granular appearance, $o$. These, which are the germinal cells or primitive ova, appear to arise in the deeper parts of the endoderm layer close to the mesoderm lamella, and as they increase in size gradually move outwards towards the surface.

Together with this increase of size the ova become spherical in shape, the protoplasm becomes very granular and opaque, and the nucleus, which at first was an ill-defined granular body, becomes vesicular, and acquires a distinct nucleolus and a very well-marked nuclear reticulum. In some of the larger ova $o$, a reticular appearance is also evident in the protoplasm.

The ovum, by its continued growth, reaches the surface of the septum, and pushing before it the surface layer of columnar epithelium, which forms the follicular investment, projects freely from the surface to which it remains attached by a short stalk (fig. 34).

In Sagartia, according to the Hentwigs, ${ }^{*}$ the ova arise in the deeper layer of the endoderm, but sink into and become invested by mesoderm before commencing their outward passage towards the surface of the ovary. I have seen no trace of such a mesodermal investment in Umbellula, neither have I seen the peculiar polar fibrillar apparatus described in Sagartia.

Structure of Zooids.-The zooids of $U$. gracilis are unique among Pennatulida, so far as at present known, in possessing pinnated tentacles.

As shown in fig. 30, the zooids cover all parts of the rachis not occupied by the polyps. The largest zooids are those at the upper end of the rachis, and it is in this situation alone that the zooids with pinnated tentacles occur. Below the polyps the zooids get gradually smaller and smaller.

Fig. 32 represents on a larger scale a group of zooids from the ventral surface of the upper extremity of the rachis, drawn with the camera. The zooids are seen to be conical, in the best marked cases tubular, projections with a mouth at the free end overhung by a single tentacle, which bears a variable number of pinnules. The pinnules may occur on one side only or on both, and in some cases form a row of five or six on each side of the tentacle.

$$
\text { * O. und R. Hertwig, Die Actinien, pp. } 95 \text { seg. }
$$


In fig. 33 one of these zooids is represented in longitudinal vertical section, together with the part of the rachis from which it springs.

The tentacle, which is hollow, overhangs the mouth on the abaxial side, a point of some interest, inasmuch as the calycular processes of the large ventral zooids of $P$. phosphorea var. aculeata were also found to be abaxial (cf. Pl. XXII. fig. 8).

The mouth $n$ leads into the stomodæum $s$, the abaxial wall of which is clothed with very long cilia $r$. At its lower end the stomodæum opens into the body cavity $h$, which is lined by endoderm, and is prolonged into the tentacle. The body cavity is, at any rate in some cases, in direct communication with that of adjacent zooids.

As in zooids generally, there are only two mesenterial filaments present, of which one is shown in the figure. These are borne by the axial septa, and are extremely long and much convoluted.

In some of the larger zooids I have noticed a slight notching of the margin of the mouth, which may possibly indicate the rudiments of additional tentacles.

Below the polyp-bearing part of the rachis the zooids become much smaller. The tentacles at first increase slightly in length, but become much more slender, and lose their pinnules, with the exception of a single one, which is often retained, giving a bifid appearance to the tentacle. These tentaculiferous zooids are, as shown in fig. 30, almost confined to the lateral margin of the rachis, the zooids of the dorsal and ventral surface becoming very early reduced to the condition of small wart-like knobs. These become smaller in size and more irregular in arrangement as we pass downwards, and finally cease about $\mathbf{5 0}$ $\mathrm{mm}$. from the upper end of the rachis.

In possessing single tentacles the zooids of $U$. gracilis resemble those of $U$. Huxleyi and U.Carpenteri, * two of the species obtained by the "Challenger" from the North Pacific and South Polar seas respectively, but differ from all other species, and indeed from all other Pennatulida yet described. In possessing pinnated tentacles the zooids of $U$. gracilis stand absolutely alone.

I have pointed out above, when discussing the nature of the zooids of $P$. phosphorea, that zooids must be considered as abortive polyps arrested in an early stage of development.

It becomes now an interesting inquiry how this unitentacular condition of the zooids of Umbellula arose. So far as is at present known, the earliest rudiments of all eight tentacles arise simultaneously in the Pennatulid polyps. I have described this above in the case of the asexually formed polyps of Pennatula

\footnotetext{
* KöLLiker, Zool. Chall. Exp., part ii. 1880, pp. 21-24.
} 
and Virgularia, and WILson * has recently shown that the same applies to the sexually produced young of Renilla. It appears, therefore, that the unitentacular condition of the Umbellula zooid is not a repetition of any stage occurring in the ontogeny of the normal Pennatulid polyp. It is, however, just possible that such a stage once existed in the phylogeny of the group, but has dropped out of its ontogeny. So far as is known, a unitentacular condition does not obtain in the ontogeny of any Alcyonarian, though we must bear in mind that very few forms have as yet been studied adequately. Among Zoantharia a temporary unitentacular condition occurs in Actinia mesembryanthemum, ${ }^{\dagger}$ while in Cerianthus and Arachnitis four tentacles arise simultaneously, and in other cases all eight.

The definite relation of the single tentacle of the Umbellula zooid to the plane of symmetry seems to indicate that it has some morphological significance, though at present we have not evidence to determine what that significance is. I would, in conclusion, direct attention to the remarkable condition of the polyps in Scytalium tentaculatum, Köll., $\ddagger$ one of the "Challenger" species, in which each polyp has but a single tentacle, as showing that a unitentacular condition may be more widely spread than is at present suspected.

Our knowledge of the genus Umbellula has been very greatly increased of late years. Two specimens taken off the coast of Greenland in 1752, and very imperfectly described, were for more than a century the only examples recorded. In 1871 LINDAHL obtained two specimens, one in Baffin's Bay in 410 fathoms, and the other at the entrance to the Omenakfjord, in N. Greenland, at a depth of 122 fathoms. An Umbellula was also obtained by NoRDENskiöld in the Kara Sea, to the east of Novaya Zemlya, during the "Vega" expedition.

The "Challenger" expedition added enormously to our knowledge of this genus, no less than seven new species being obtained from widely different parts of the world. Concerning the geographical distribution of this genus Kölliker says:- "After having known for more than a century only one locality, the North Polar Sea, near the coast of Greenland, we have now learned that this form is far and widely distributed. Umbellulce have now been obtained from the North Atlantic Ocean (between Portugal and Madeira); from the North Polar Sea, coast of Greenland; from the Atlantic Ocean, under the Equator, between Africa and America, and from the west coast of Africa, north of Sierra Leone (Stud.); from the South African Sea, west of Kerguelen Island; from the South Polar Sea; from the coasts of New Guinea and of

* Wilson, "The Development of Renilla," Proc. Roy. Soc., 1882.

$\dagger$ LaCazE-Duthiers, "Développement des Coralliaires," Archives de Zoologie expérimentale et générale, vol. i. 1872, and vol. ii. 1873.

$\ddagger$ KölLIKER, Zool. Chall. Exp., part ii., 1880, pp. 10, 11, and pl. iii. fig. 12, pl. iv. fig. 13. 
Japan; and from the middle of the North Pacific Ocean. Umbellula has, therefore, of all genera of Pennatulida, the widest distribution."*

The "Triton" specimen makes a very interesting addition both to the list of species of Umbellula and to the localities in which it has been found.

The measurements of the sole specimen of Umbellula gracilis yet known are as follows :-

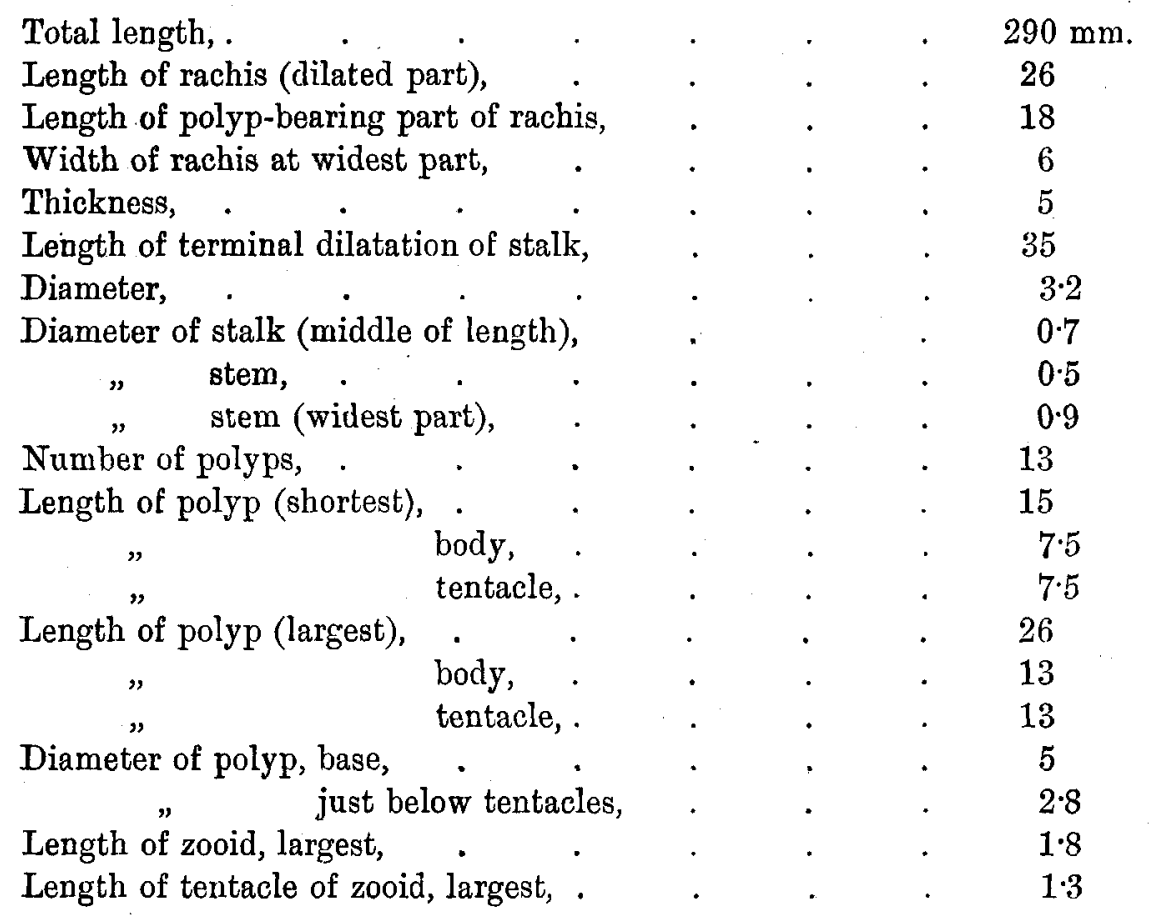

GENERAL OBSERVATIONS.

Geographical Distribution.

Horizontal Distribution. - The most noteworthy point is the great abundance and variety of specimens dredged at one particular locality,一Station 11. At this place there were obtained, from a depth of 555 fathoms, nineteen specimens of Pennatula phosphorea var. aculeata; three specimens of Virgularia tuberculata, a new species; one specimen of Dïbenia abyssicola var. smaragdina, a form hitherto found only off the Norwegian and Swedish coasts ; thirty specimens of Kophobelemnon stelliferum var. dura; and one specimen of Umbellula gracilis, a new species; i.e., example of five out of the fourteen known families of Pennatulida, of three distinct subsections, and two of the four sections of the order were obtained at this one spot.

* KöLliker, Zool. Chall. Exp., part ii. 1880, p. 37. 
This extraordinary profusion mark the locality as a very exceptional one.

At each of the other stations only single species were obtained.

Vertical Distribution.-The "Triton" observations have increased the vertical range of Pennatula phosphorea to 555 fathoms, its previously recorded limit being 340 fathoms; of Dübenia abyssicola, from 120 to 555 fathoms; of Kophobelemnon stelliferum v. durum, from 300 to 640 fathoms; and have added a new deep water Virgularia, V. tuberculata, extending to 555 fathoms, to the sole one previously known, $V$. bromleyi.

These results, so far as they go, do not lend any very material support to KöLLIKER's conclusion, that " the simpler forms of Pennatulida, especially those with sessile polyps, inhabit great depths."**

KöLLIKER ranks among primitive forms of Pennatulida the Umbellulidoe, which are an essentially deep water family, seven out of the twelve known species being found below 1000 fathoms and five below 1800 fathoms, and cites this distribution in evidence of the view that the lower forms of Pennatulida are, as a rule, deep water forms.

Umbellula appears to me, however, to be not a primitive form but a highly mudified one. This is shown by the great length of the non-polypiferous as compared with the polyp-bearing part of the colony, i.e., the great preponderance of the purely colonial portion; by the great difference between the polyps and the zooids; by the extreme differentiation of some of the zooids; and, above all, by the polymorphism of the zooids themselves, an almost unique condition among Pennatulids. In all these respects Umbellula is far less primitive than Funiculina, which is essentially a shallow water form, attaining its maximum of development at about 30 fathoms depth.

A point of considerable interest concerns the influence of increase in depth on the structure and habits of Pennatulids. On this point but little can be said at present for want of sufficient evidence.

We have seen above that some of the deep water forms (below 500 fathoms) have much thicker body walls and layers, and more numerous spicules, than those from less depths. If we compare different genera together there would appear to be no relation whatever between depth of water and development of spicules; thus Umbellula gracilis and Virgularia tuberculata from 555 fathoms have no spicules at all; while $P$. phosphorea and $K$. stelliferum, brought up in the same dredge with the preceding species, have exceptionally large and numerous spicules. If, however, we confine ourselves to one species, we seem to find such a relation; thus the specimens of Pennatula phosphorea from below 500 fathoms have very much thicker walls, and larger and more abuudant spicules, than those from 20 to 40 fathoms. In this case we have strong reason

* Kölliker, Zool. Chall. Exp., part ii. 1880, p. 39. 
for thinking, from the small size and somewhat stunted appearance of the deep water specimens, that the species is typically a shallow water one, and it is very possible that the increase in development of spicules is due directly to the change of environment.

All the specimens of Kophobelemnon and also those of Pennatula obtained below $\mathbf{5 0 0}$ fathoms contain large quantities of sand mixed with Foraminifera shells, both in the polyp cavities and in the tentacular cavities, and also encrusting the exterior. The specimens of Umbellularia, Dïbenia, and Virgularia brought up at the same time are, however, perfectly clean and free from sand. Whether this indicates difference in habits or is merely accidental, I have no means of ascertaining; the specimens of Pennatula from shallow water have no sand in the polyp cavities, or but very little.

Morphology. - The chief points of morphological interest on which light is thrown by the "Triton" specimens appear to concern the structure of the zooids of Pennatula and Umbellula; and the relations of the plane of symmetry of the polyps established in Pennatula, Kophobelemnon, and Umbellula.

\section{DESCRIPTION OF THE FIGURES ON PLATES XXI.-XXV.}

All the figures were drawn with the camera. Figures 8,28 , and 33 are not taken from single sections, but are constructed from a number of separate camera drawings of the several parts shown. The numbers beneath the figures indicate in diameters the magnifying power employed in each case.

\section{Alphabetical List of References.}

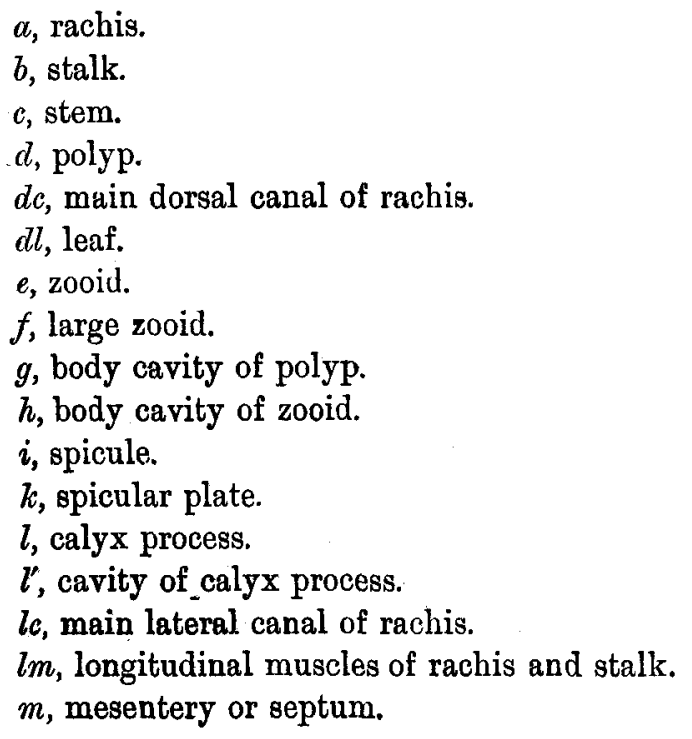

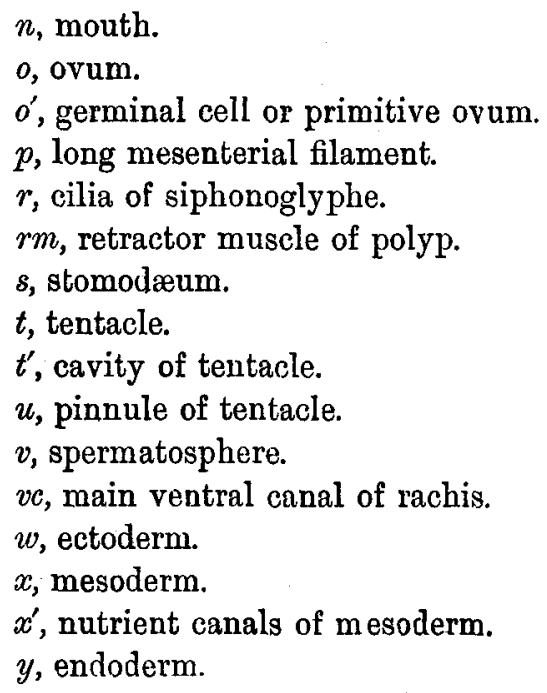




\section{Plate XXI.}

Fig. 1.-Virgularia tuberculata; ventral surface. $\times 3$.

Fig. 2.-Virgularia tuberculata; portion of rachis, ventral surface, showing arrangement of polyps in groups of threes; also the tubercular calyx processes and the varying conditions of the calyx during retraction of the polyp. $\times 17$.

Fig. 3.-Virgularia tuberculata; two spermatospheres from lower part of rachis of the specimen shown in fig. $1 . \times 70$.

Fig. 4.-Pennatula phosphorea var. aculeata; from right side. Shows characteristic shape of leaves, also both small and large zooids. $\times 2$.

Fig. 5.-Pennatula phosphorea var. aculeata; transverse section of rachis with one entire leaf and the base of the corresponding one of the other side. Shows shape of leaf; shape and arrangement of zooids both large and small; great thickness of wall of rachis, and small size of its main canals. $\times 4$.

Fig. 6.-Pennatula phosphorea; transverse section of rachis with entire leaf of normal form, for comparison with fig. 5 . Shows great width of leaf, absence of large zooids, thinness of walls of rachis, and large size of main canals. $\times 4$.

Fig. 7.-Pennatula phosphorea var. aculeata; lower end of rachis from left side. Shows stages in development of polyps, and especially the simultaneous appearance of the calyx processes and of the tentacles; also the primitive independence of the polyps of one another. $\times 17$.

\section{Plate XXII.}

Illustrating the anatomy of the large ventral zooids of Pennatula phosphorea var. aculeata.

The reference letter $t^{1}$ in the figures on this plate should be $l^{1}$.

Fig. 8.-Longitudinal section of large ventral zooid and of the part of the rachis from which it arises. Shows structure of large zooid and of one of the small zooids. $\times 50$.

Fig. 9.--Transverse section of a calyx process of a polyp, for comparison with the succeeding figure. $\times 150$.

Figs. 10 to 16.-Transverse sections through one of the large ventral zooids at various parts of its height, fig. 10 being close to the apex and fig. 16 at the base of attachment to the rachis. $\times 150$.

Fig. 10.-Through upper end of zooid, showing one calycular cavity.

Fig. 11.-Lower down; shuws two calycular cavities.

Fig. 12.-Lower down still; shows three calycular cavities.

Fig. 13.-Through upper part of mouth; shows long cilia of siphonoglyphe.

Fig. 14.-Through lower part of mouth; shows five calycular cavities.

Fig. 15.-Through stomodæum about the middle of its length. Shows eight septa and septal chambers.

Fig. 16.-Through lower part of polyp cavity, showing the two mesenterial filaments, and the remains of the other six septa.

\section{Plate XXIII.}

Fig. 17.-Dübenia abyssicola var. smaragdina. Ventral surface. $\times 3$.

Fig. 18.-Dübenia abyssicola var. smaragdina. Portion of rachis from left side. Shows arrangement of polyps in pairs, each pair embraced at base by a fan-shaped spicular plate. $\times 17$.

VOL. XXXII. PART I. 
Fig. 19.-Dübenia abyssicola var. smaragdina. Portion of rachis from dorsal surface. Shows arrangement of polyps and zooids. $\times 17$.

Fig. 20.-Dübenia abyssicola var. smaragdina. Tentacle of polyp, showing rib of calcareous spicules. $\times 70$.

Fig. 21.-Dübenia abyssicola var. smaragdina, one of large spicules of spicular plate. $\times 55$.

Fig. 22.-Funiculina quadrangularis. Portion of rachis of young specimen from left side. Shows shape of polyp in state of extreme contraction; also extension of spicules down whole length of polyps and on to rachis. $\times 7$.

\section{Plate XXIV.}

Kophohelemnon stelliferum var. durum.

Fig. 23.-Whole specimen, dorsal surface; showing typical arrangement of polyps. $\times 2$.

Fig. 24.-Tentacle of polyp; showing rib of calcareous spicules extending whole length of tentacle and along pinnules. $\times 20$.

Fig. 25.-Transverse section of tentacle, showing tentacular cavity and extension into pinnules, also urrangement and shape of spicules. $\times 70$.

Fig. 26.-Two large spicules from spicular rib of tentacle. $\times 55$.

Fig. 27.-Transverse section of stalk; showing arrangement of spicules and muscles; als 3 shape of stem and of main longitudinal canals. $\times 30$.

Fig. 28.-Transverse section of rachis passing through three polyps at different portions of their length. The left-hand polyp is cut horizontally ( $c f$. fig. 23), and shows stomodæum, mouth, and tentacles; the right-hand polyp is cut transversely through the lower portion of the stomodæum, and shows arrangement of retractor muscles and position of plane of symmetry of polyp; the third or dorsal polyp is cut transversely at a still lower level, and shows the two mesenterial filaments and a number of ova. The section also shows several zooids and the shape and position of the stem and of the main ventral canal. $\times 30$.

\section{Plate XXV.}

\section{Umbellula gracilis.}

Fig. 29.-Whole specimen; dorsal surface. $\times 1$.

Fig. 30.-Rachis; ventral surface. Shows arrangement of polyps and zooids. $\times 2$.

Fig. 31.-Tentacle of polyp; shows alternation of large and small pinnules. $\times 10$.

Fig. 32.-Apex of rachis; ventral surface. Shows shape and arrangement of large zonids with pinnate tentacles. $\times 14$

Fig. 33.--Longitudinal section of one of the large zooids; shows the tentacle with its pinnules, mouth, stomodæum, mesenterial filament, \&c. $\times 55$.

Fig. 34.- Section of septum bearing ova, and of the part of the body wall of the polyp from which the septum arises. Shows also the disposition of the retractor musele. $\times 70$.

Fig. 35. - Section of ovigerous septum close to its free edge, showing various stages in the early development of the ova. $\times 470$. 


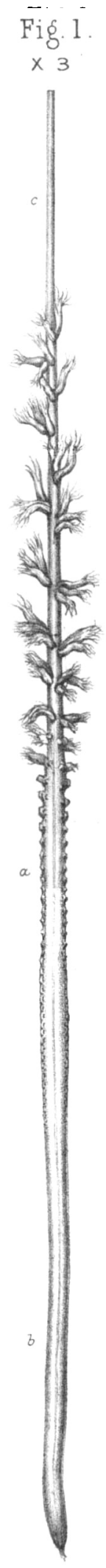

$$
\begin{aligned}
& \text { Fig. } 5 \text {. } \\
& \times 4
\end{aligned}
$$
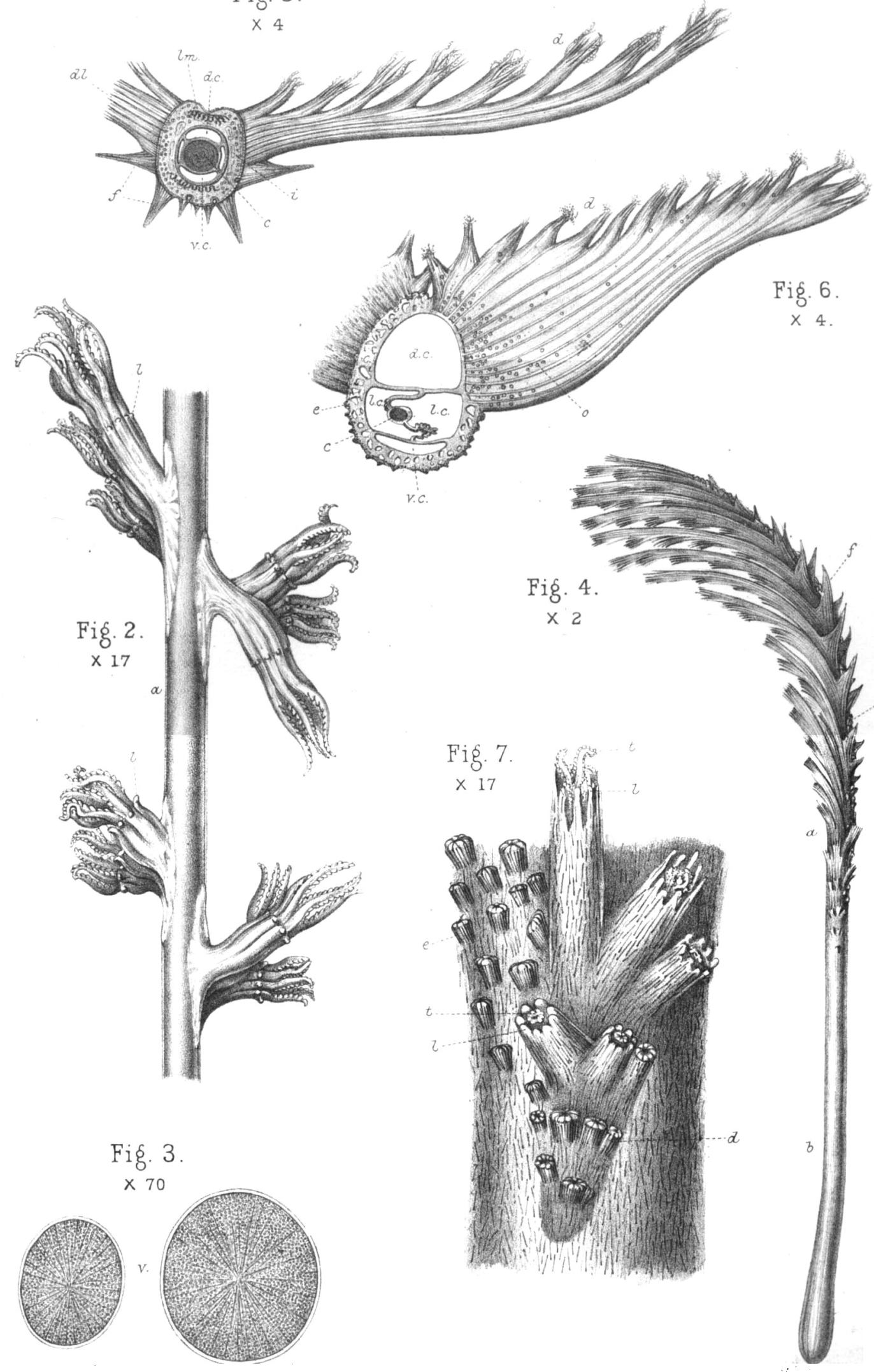

Fig. 6.

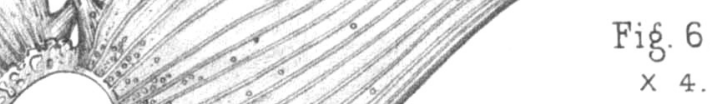




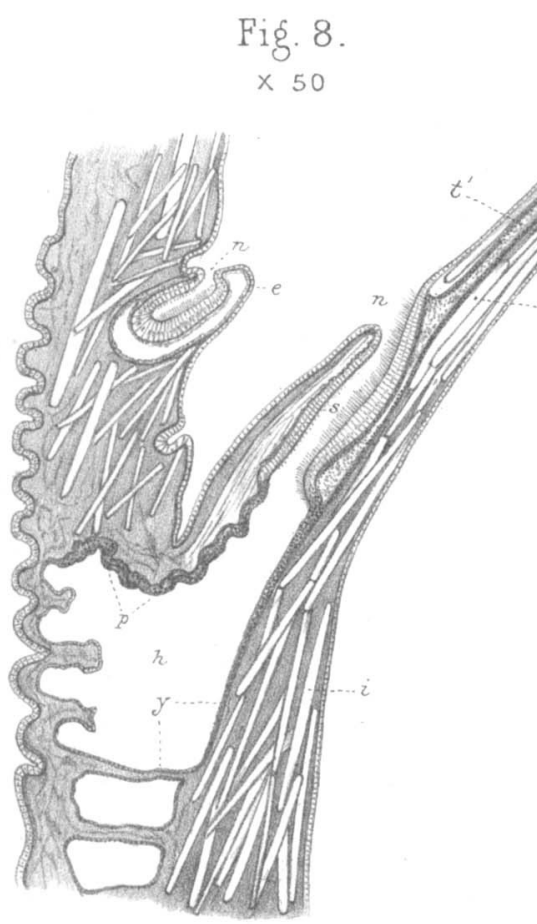

Fig. 11

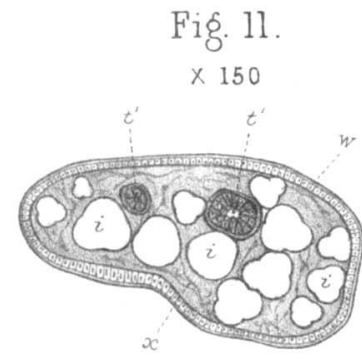

Fig. 14.

$\times 150$

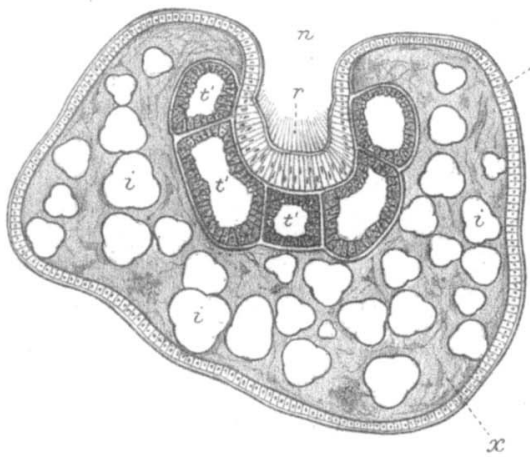

Fig. 15.

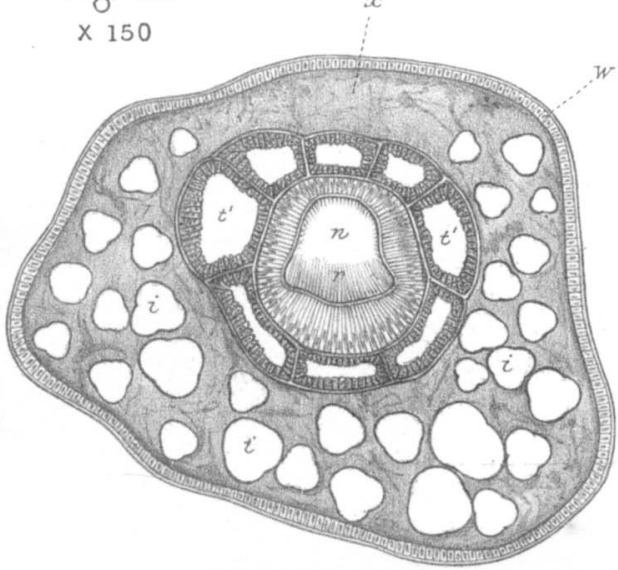

Fig. 9.

$\times 150 t^{\prime} \quad w$

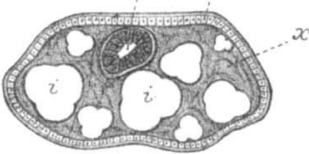

Fig 10.

$\times 150$

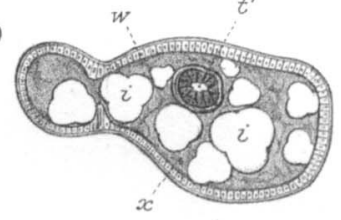

Fig. 12.

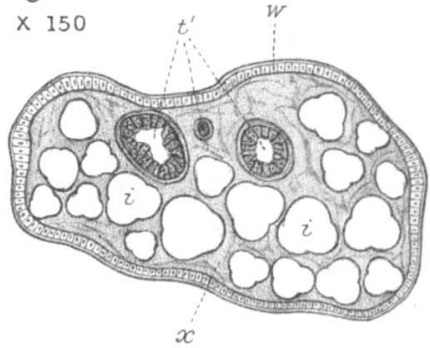

Fig. 13.

$\times 150$

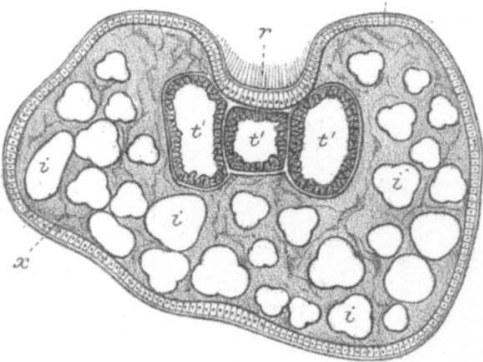

Fig. 16

$\times 150$

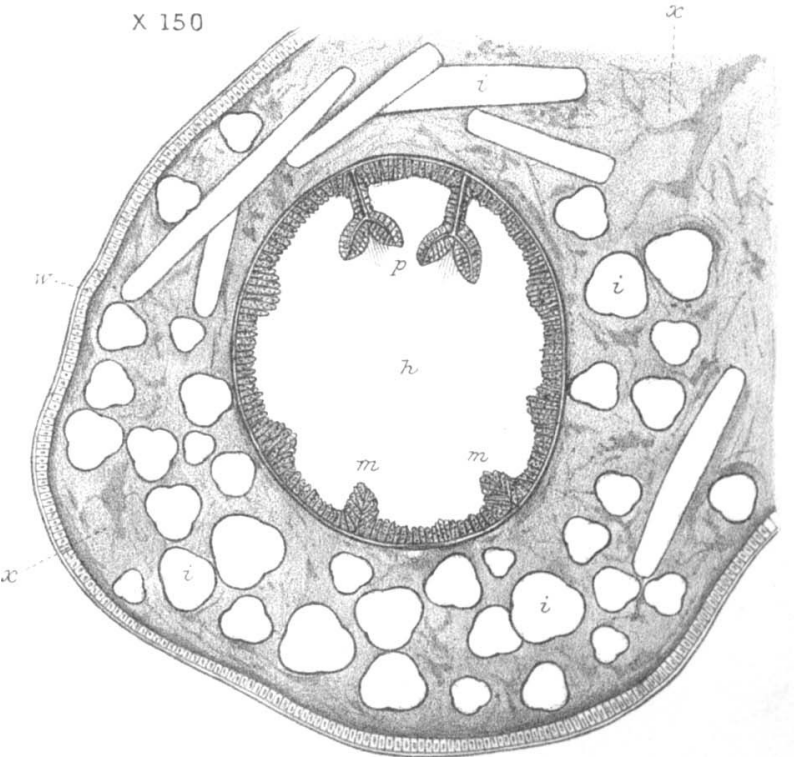


Vol.XXXI, Pl. XXIII.

Fig. 21 .

Fig. 18.

Fig. 17.

$\times 17$

$x$
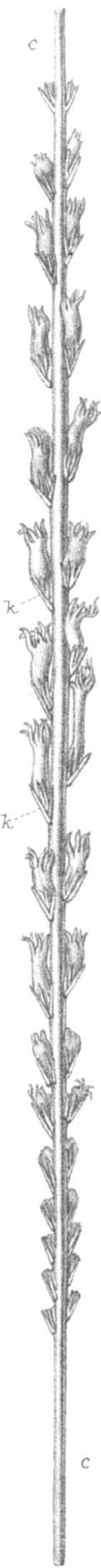

Fig. 19.

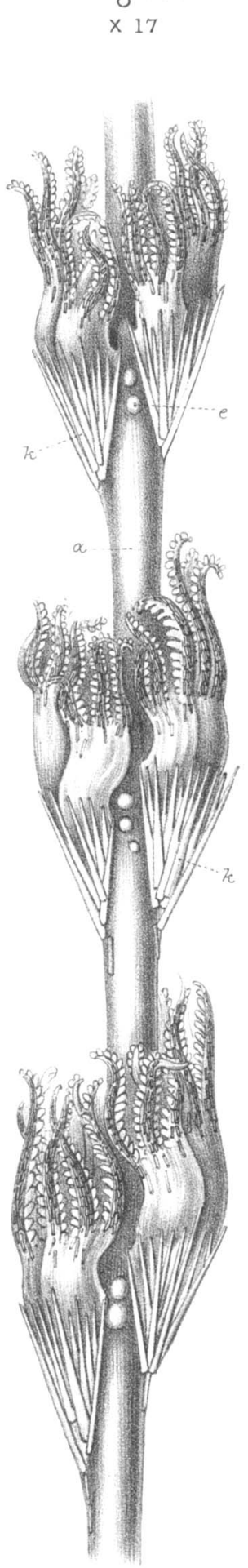

Fig. 20.

$\times 70$

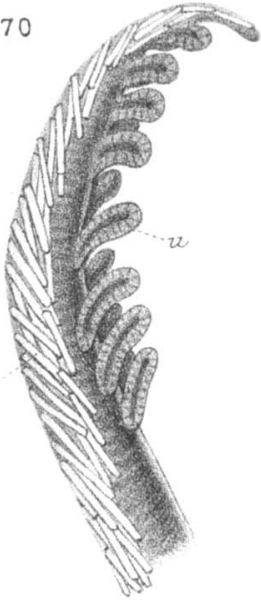

$\times 55$

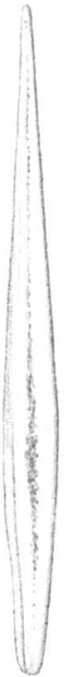

Fig. 22

$\times 7$

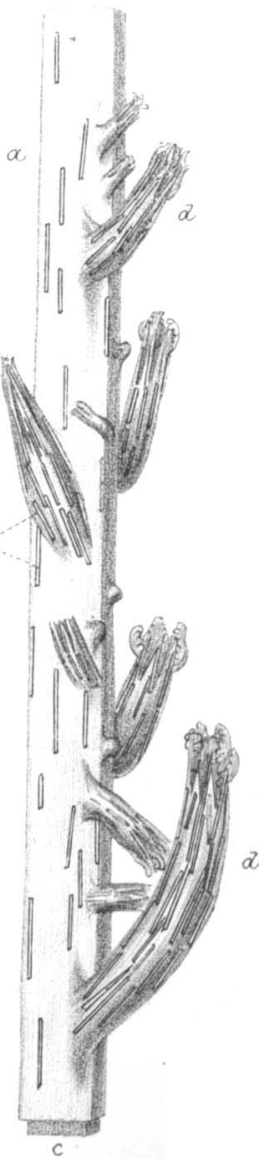

DÜBEN|A. FUNICULINA. 
Fig. 23.

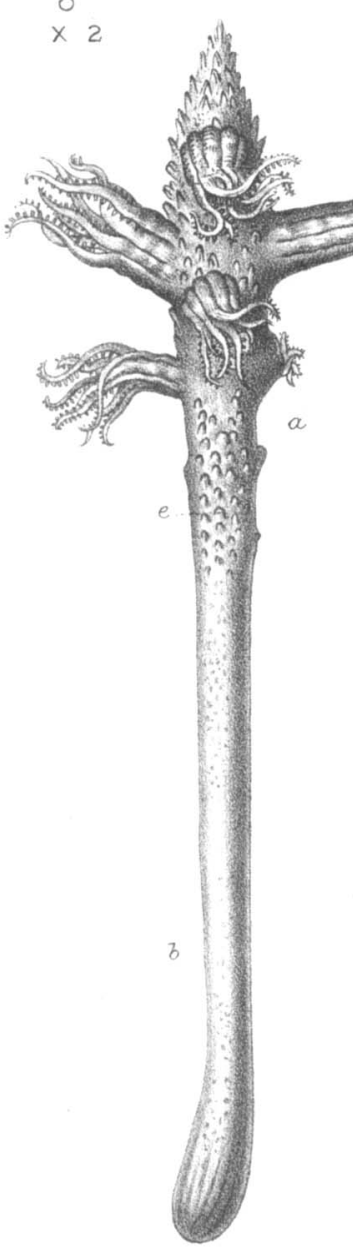

Fig. 26.

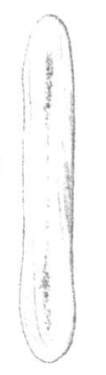

Fig. 25

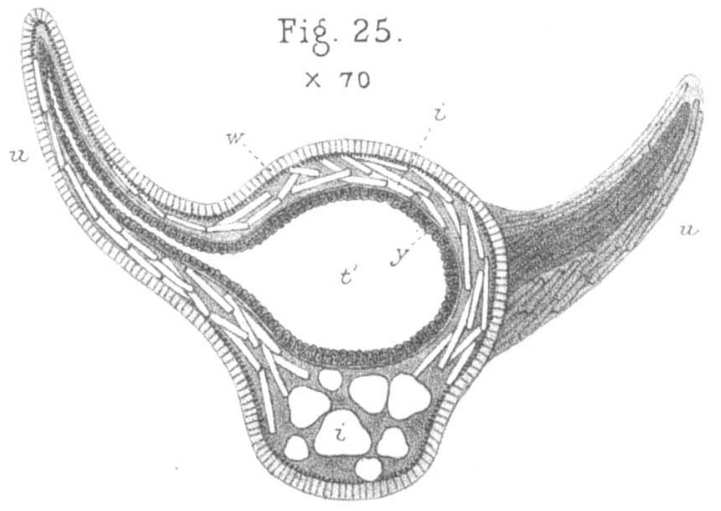

Fig. 27.

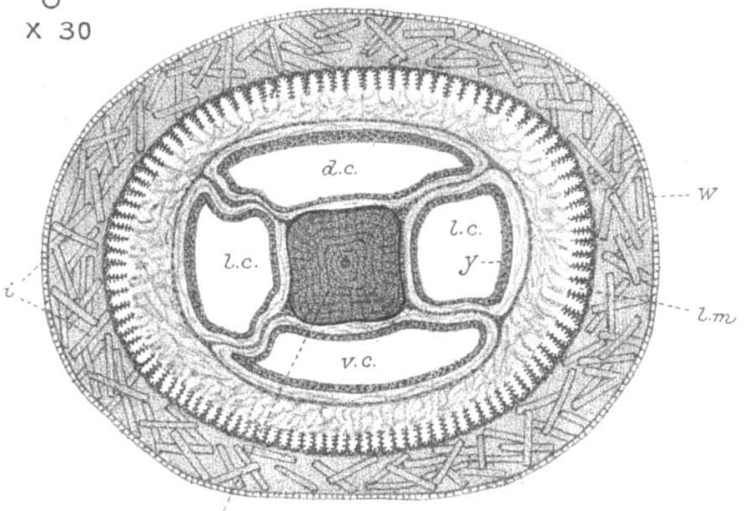

Fig 24 .

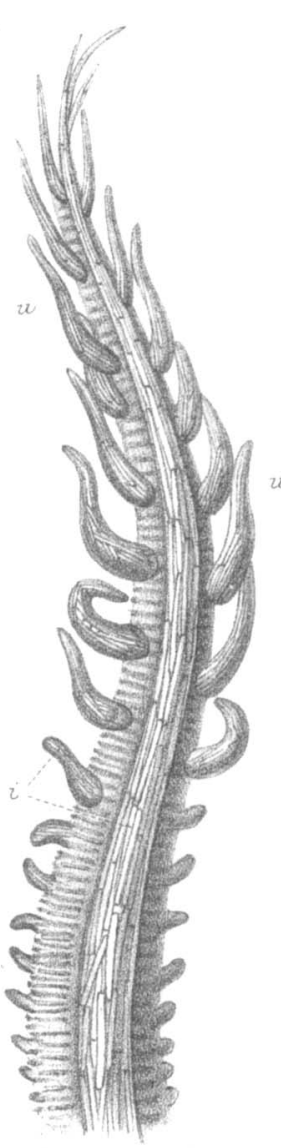

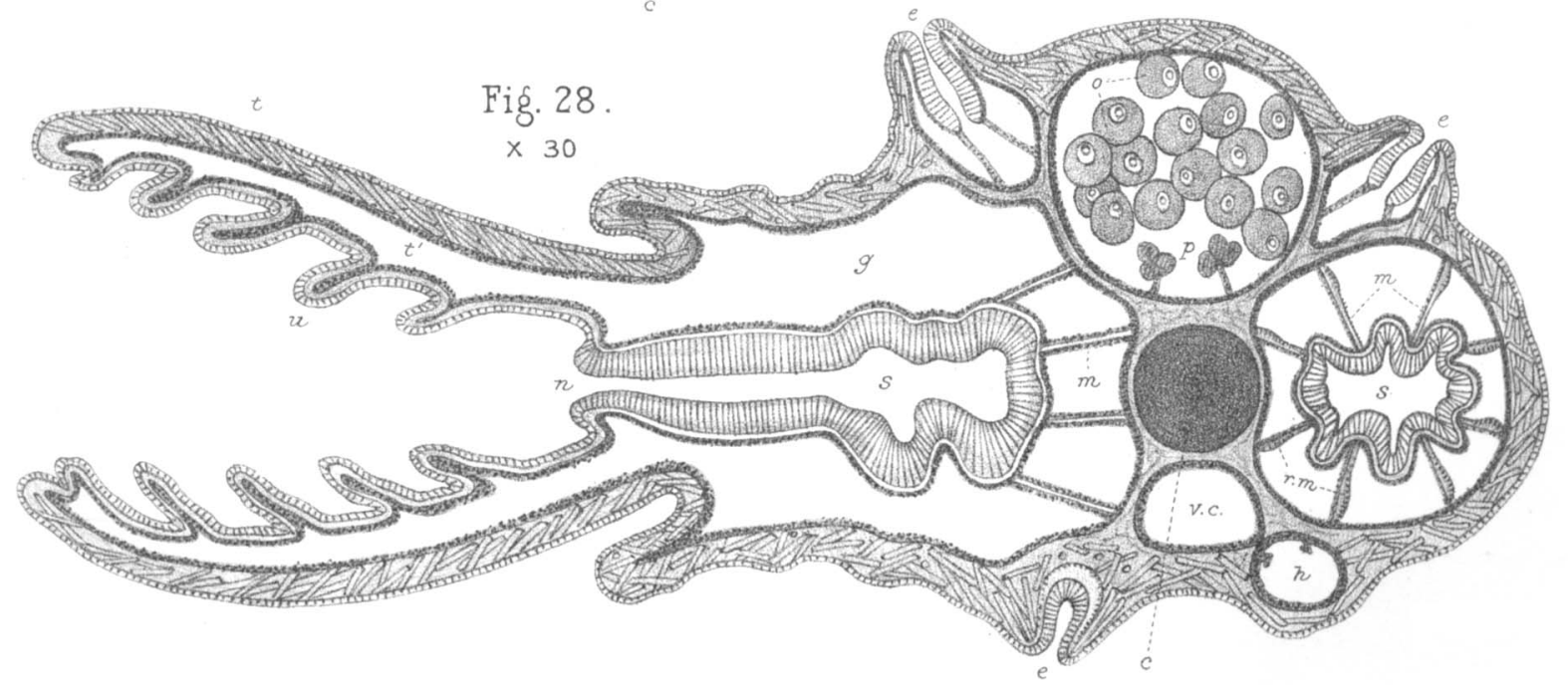



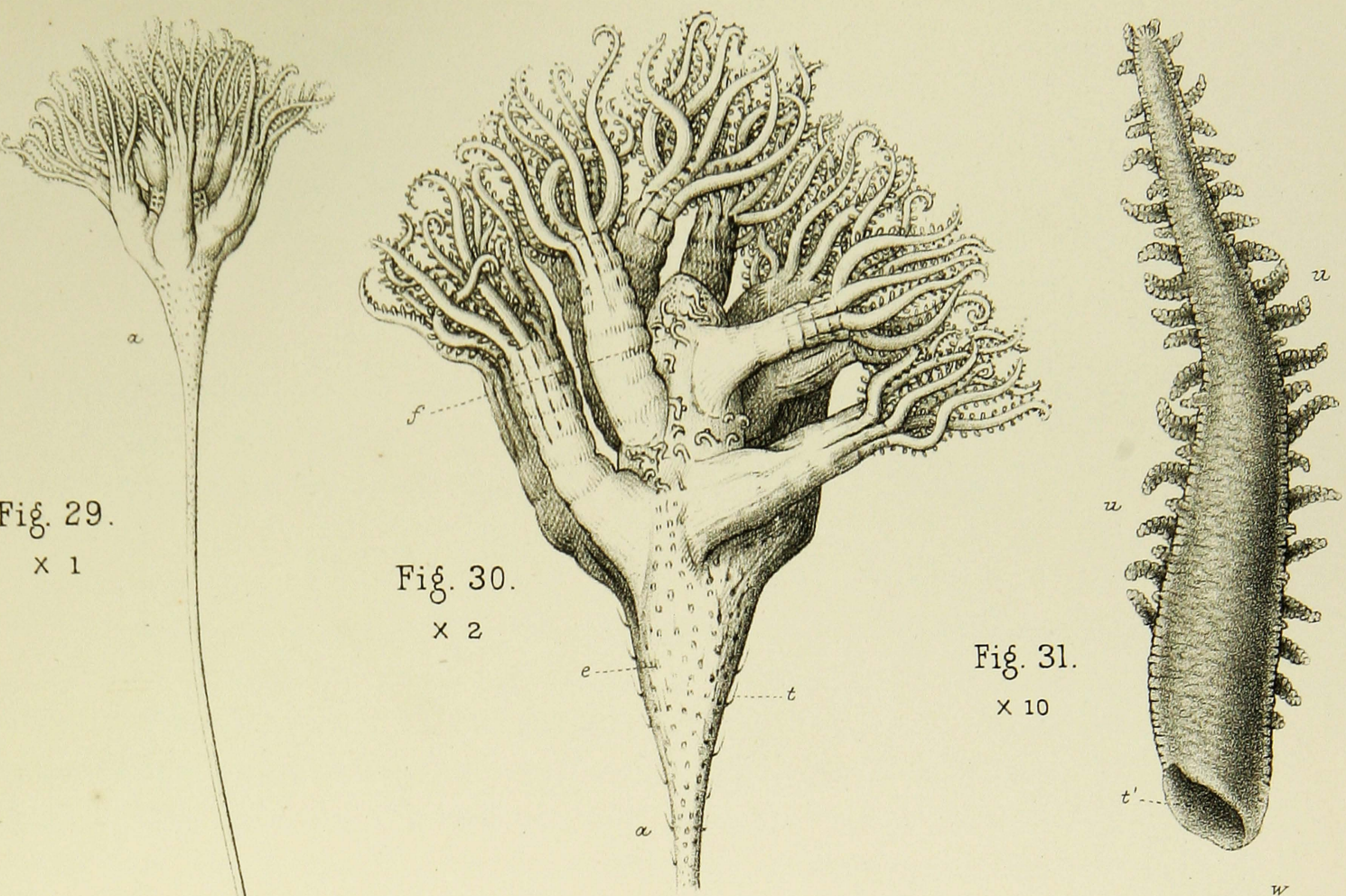

Fig. 32 .
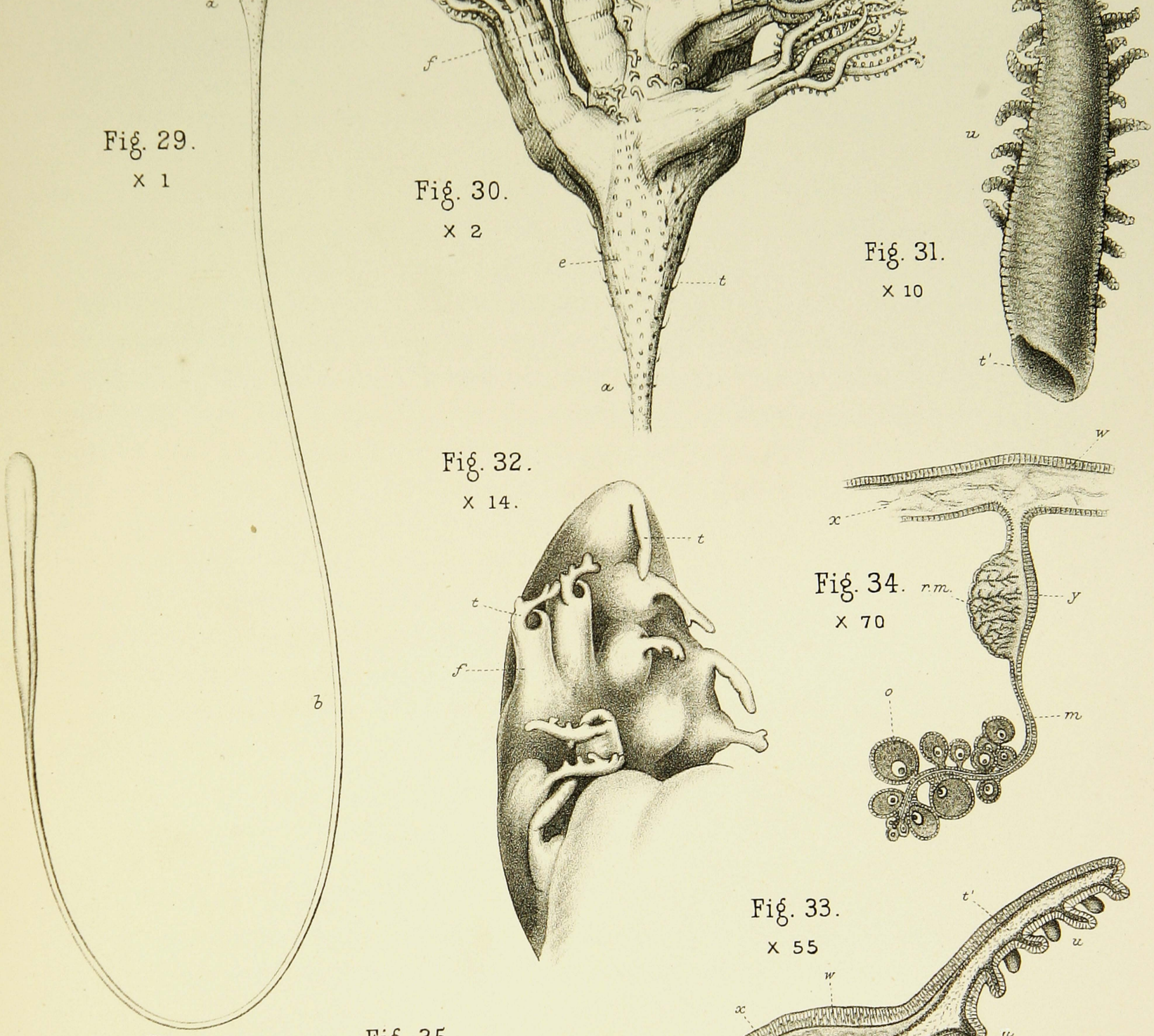

Fig. 35

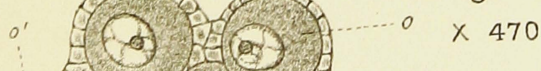

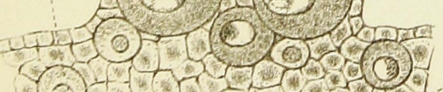

(6) 5 (⿻)

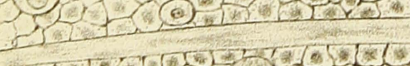
5) $x+x^{2}, 5$
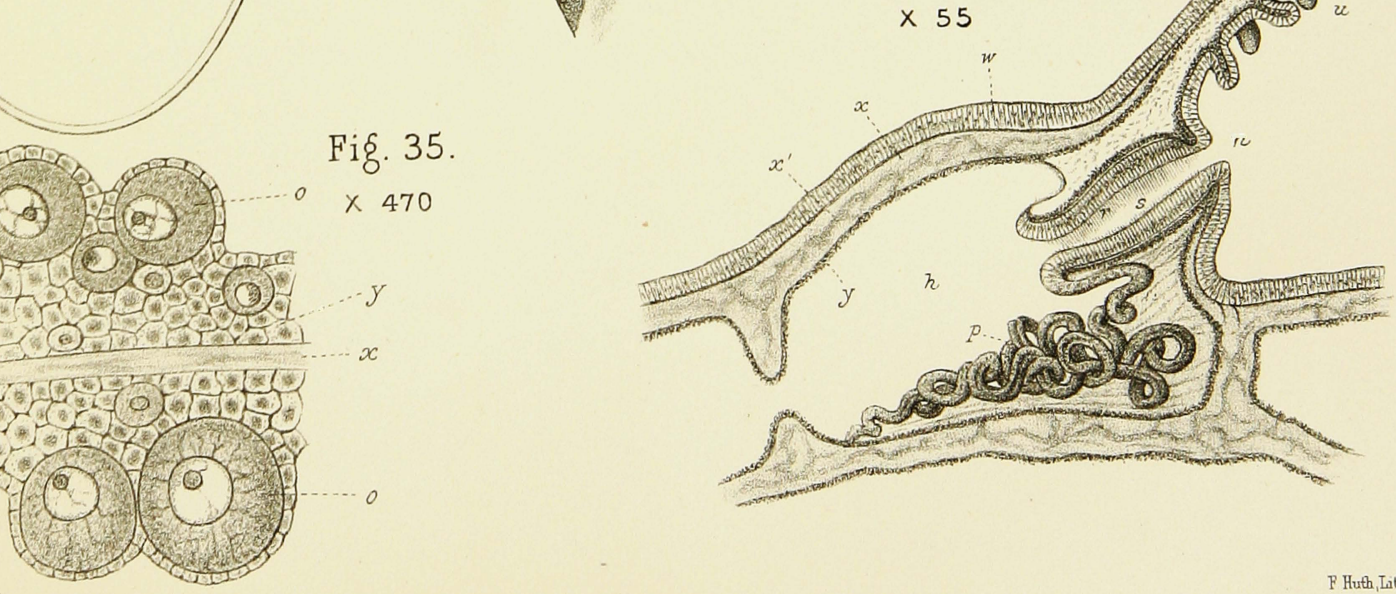